NBER WORKING PAPER SERIES

\title{
EFFICIENCY AND THE BEAR: \\ SHORT SALES AND MARKETS AROUND THE WORLD
}

\author{
Arturo Bris \\ William N. Goetzmann \\ Ning Zhu \\ Working Paper 9466 \\ http://www.nber.org/papers/w9466 \\ NATIONAL BUREAU OF ECONOMIC RESEARCH \\ 1050 Massachusetts Avenue \\ Cambridge, MA 02138 \\ January 2003
}

We thank Gerard Goetz for excellent research assistance, and to Frank Fabozzi for considerable help in obtaining the data used in this paper. The views expressed herein are those of the authors and not necessarily those of the National Bureau of Economic Research.

(C2003 by Arturo Bris, William N. Goetzmann and Ning Zhu. All rights reserved. Short sections of text not to exceed two paragraphs, may be quoted without explicit permission provided that full credit including notice, is given to the source. 
Efficiency and the Bear: Short Sales and Markets around the World Arturo Bris, William N. Goetzmann, and Ning Zhu

NBER Working Paper No. 9466

January 2003

JEL No. G0

\begin{abstract}
$\underline{\text { ABSTRACT }}$
We analyze cross-sectional and time series information from forty-seven equity markets around the world, to consider whether short-sales restrictions affect the efficiency of the market, and the distributional characteristics of returns to individual stocks and market indices. Using the approach developed in Morck et.al. (2000) we find significantly more cross-sectional variation in equity returns in markets where short selling is feasible and practiced, controlling for a host of other factors. This evidence is consistent with more efficient price discovery at the individual security level. A common conjecture by regulators is that short-selling restrictions can reduce the relative severity of a market panic. We test this conjecture by examining the skewness of market returns. We find that in markets where short selling is either prohibited or not practiced, returns display significantly less negative skewness, and the frequency of extreme negative returns is lower. On the other hand, the overall volatility of individual returns and market returns is higher.
\end{abstract}

William N. Goetzmann

Yale School of Management

International Center for Finance

Box 208200

135 Prospect Street

New Haven, CT 06520-8200

and NBER

william.goetzmann@yale.edu

Arturo Bris

Yale School of Management

International Center for Finance

Box 208200

135 Prospect Street

New Haven, CT 06520-8200

arturo.bris@yale.edu
Ning Zhu

Yale School of Management

International Center for Finance

Box 208200

135 Prospect Street

New Haven, CT 06520-8200

ning.zhu@yale.edu 


\section{Introduction}

In February of 1609, a group of well-connected Dutch businessmen, led by one of the original subscribers to the Dutch East India Company, Isaac Le Maire, formed a secret association, a "Groote Companie," to short the shares in the East India Company in anticipation of the incorporation of a rival French-chartered trading firm. Le Maire and his colleagues sold shares forward in a "blanco" transaction promising future delivery in one or two years. Over the next twelve months, their profits mounted, as East India Company shares dropped by 12\%, angering shareholders who inevitably learned of their plan. In January of 1610, a year after the formation of the "Groote Companie" and only three years after the official founding of the Amsterdam Exchange, the first regulation against short selling was enacted. Share prices rebounded, a rival French company was not formed and Isaac Le Maire never succeeded in disentangling himself from the litigation that ensued. ${ }^{1}$

At various times over the next four hundred years, short-sellers have been blamed for stock market declines, and market participants have called for regulation against short sales. ${ }^{2}$ However, despite centuries of disagreement between speculators and regulators on the topic, no one really knows whether short-sales constraints are a good or a bad thing. As the above example indicates, short-sales restrictions are nearly as old as organized exchanges, and yet there is little empirical evidence on whether they prevent or facilitate market crashes, or whether they hinder or help rational price discovery.

In this paper, we use cross-sectional and time series information from forty-seven equity markets from around the world to examine the question of whether short-sales restrictions affect

\footnotetext{
${ }^{1}$ This account is taken from Montias, John Michael, 1989, Vermeer and His Milieu, Princeton Press, Princeton, p. 20. The original study of the Le Maire affair may be found in J. G. van Dillen, 1930, "Isaac Le Maire en de handle in action der Oost-Indische Companie," Economisch-historisch Jaarboek 16:46, 107-111. For a discussion on the legal and ethical view of short-selling in late Sixteenth Century Holland, see De Marchi and Harrison (1994).
} 
the efficiency of the market and the distributional characteristics of individual as well as market returns. We obtain information regarding the history and current practice of short-sales restrictions from market regulators, investment banks, and institutional investors specialized in short sales. This dataset allows us to characterize each country in terms of the legality, as well as the practice, of short selling for the period 1990-2001. Using the approach developed in Mørck, Yeung and Yu (2000) [MYY] we find significantly more cross-sectional variation in equity returns in markets where short selling is feasible and practiced, controlling for a host of other factors. This evidence is consistent with more efficient price discovery at the individual security level.

A common conjecture by regulators is that short-sales restrictions can reduce the severity of price declines. We test this conjecture by examining the skewness of market returns. We find some evidence in favor of the conjecture. That is, we find that the lifting of short-sales restrictions is associated with increased negative skewness in individual stock returns. Our result is thus consistent with the regulatory views of Samuel Untermyer, legal counsel to the 1913 Pujo Committee of Congress investigating money trusts. In his devastating questioning of Frank Stugis, president of the New York Stock Exchange from 1894 to 1898, Untermyer succinctly articulated the public fear of short selling during a financial crisis.

Untermyer: Under what circumstances would you regard... short selling as legitimate and proper?

Stugis: I should regard it so if there was a panic raging over the country and it was desirable to protect interests which could not be sold. I think it would be a perfectly legitimate thing to do.

Untermyer: Let us see about that. If there was a panic raging over the country and a man sold stocks short, would not that simply add to the panic?

\footnotetext{
${ }^{2}$ For an excellent review of the history of short-sales restrictions, see "A Short History of the Bear," by Edward Chancellor, October 29, 2001, copyright David W. Tice and Co.

http://www.prudentbear.com/press_room_short_selling_history.html
} 
Stugis: It might. Self preservation is the first law of nature. ${ }^{3}$

This view is echoed by one of the regulators whom we contacted to obtain data for our sample. In his words: "forbidding short selling prevents big market swings since the market size is limited." Our analysis sheds light on the costs and benefits of short-sales regulation at the individual security level and at the market level. On the one hand, our data strongly support the view that short selling facilitates efficient price discovery - at least to the extent that efficiency is captured empirically by the lack of synchronous movement in daily returns. On the other hand, short selling may also facilitate severe price declines in individual securities, at least as defined in terms of negative skewness. Despite the relationship between short sales constraints and skewness at the individual security level, we find little compelling evidence that short-sales constraints prevent or mitigate severe price declines at the market level. In particular, we do not find that short-sales constraints prevent market crashes. Figure 1 summarizes our findings regarding the skewness of the market and the synchronicity of stock returns. We plot both variables depending on whether countries allow and commonly practice short sales or not. In this figure we do not control for a number of factors that potentially influence co-movement and skewness, however the raw data is somewhat instructive. Countries in which short-sales are practiced display less co-movement and modestly more negative skewness.

\section{[Insert Figure 1 here]}

Note that some countries — Hong Kong, Malaysia, Norway, Sweden, and Thailand — appear twice on the figure. This is because they lifted short-sales constraints in the period of our study. For example, short-sales restrictions for Sweden were eliminated in 1991. Before that date, 93 percent of the stocks moved together, and the market skewness was -0.50 . In the

\footnotetext{
${ }^{3}$ Untermyer, Samuel, 1915, "Speculation on the Stock Exchanges and Public Regulation of the Exchanges,"
} 
period since 1991, the comovement of stocks declined to 76 percent, and the market skewness increased to -0.04. Sweden's positional shift in the figure is the common pattern among the countries that relaxed short-sales constraints. ${ }^{4}$ The international evidence shown in Figure 1 at least suggests that short-sales might play an important role in efficiency and market crash probability. In the remainder of this paper, we investigate these potential relationships in econometric detail.

The paper is organized as follows. In the next section we review the current literature on short-sales and discuss our contributions in the context of related research. In Section 3 we summarize the range of short-sales regulations and practices in markets around the world. Section 4 reports the results of the MYY test of relative pricing efficiency. Section 5 reports the statistical characteristics of market and security returns associated with short-sales and tests for differences in skewness conditional upon restrictions. Section 6 concludes.

\section{Literature Review}

Short-sales play an important role in asset pricing models and the theory of portfolio choice. Most neo-classical models in finance (c.f. Ross, 1976) rely upon the ability of market participants to take off-setting positions in close economic substitutes in order to enforce a law of one price. Considerable research in the last decade has explored the effects of short-sales and frictions in an asset market. For example, Luttmer (1993), Chen (1995, 2001), He and Modest (1997), Hansen and Jagannathan (1997), Jouini and Kallal (2001), Duffie, Garleanu and Pedersen (2002) all address the effect of market frictions and seek to characterize the magnitude of mispricing that may obtain. Diamond and Verecchia (1987) explore the effects of short-sales

\footnotetext{
American Economic Review, 5(1) Supplement, Papers and Proceedings, pages 24-68.

${ }^{4}$ Section VI.A in the paper shows that the difference in skewness before and after the change in regulation is not significantly different from zero.
} 
constraints on the speed of price-adjustment to private information. Recently, Hong and Stein (2002) develop a heterogeneous agent model linking short-sales constraints to market crashes. In their model, if some investors are constrained from selling short, their accumulated unrevealed negative information will not be manifest until the market begins to drop, which further aggravates market declines and leads to a crash. They motivate the model with the observation that the U.S. market displays negative skewness.

Most of the research cited above suggests that short-sales constraints have an adverse effect on efficiency - the only question is how much. On the other hand, an interesting exception is the argument of Allen and Gale (1991) who point out that the potential for financial innovation renders short selling a destabilizing influence in the economy. This is potentially interesting in light of our findings that short sales tend to be allowed in major markets where financial innovations occur-particularly with respect to capital structure and new security development -- and that these markets also tend to display relatively higher negative skewness in returns. Bernardo and Welch (2002) develop a model describing how the fear of financial crisis, instead of a real liquidity shock, is the true cause of financial crises. One implication of their model is that putting constraints that hinder some market participants from front-running other investors can effectively prevent financial crisis from happening, supporting the finding of Allen and Gale (1991) that short sales can potentially destabilize the economy.

Empirical evidence on short selling largely supports the theoretical view that constraining it hinders price discovery. In a recent paper, Jones and Lamont (2002) use early $20^{\text {th }}$ Century U.S data to show that stocks which are expensive to short have high valuations and low subsequent returns. Their finding is consistent with the hypothesis that difficult-to-short stocks are overpriced. Using data on DotComs, Ofek and Richardson (2002) show that short-sales constraints, in the form of stock option lock-ups, have considerable and persistent negative impact on 
subsequent stock returns, also supporting the argument that stock prices do not fully incorporate information under short-sales constraints. Geczy, Musto, and Reed (2002) use a comprehensive dataset of short sales, and find that short-selling restrictions have a mixed impact on the profitability of well-known arbitrage strategies.

Short selling requires the ability to borrow securities. As we will discuss in this study, securities borrowing and lending can directly determine the costs of short selling and hence should be considered in conjunction with short-sales constraints. In our empirical analysis, we classify countries into categories according to whether short selling is practiced. Although short selling is allowed in some countries, securities borrowing and lending is so limited that short sales are not really feasible. D'Avolio (2002) provides empirical evidence about securities borrowing and lending in U.S. stock markets that demonstrates considerable cross-sectional variation in the feasibility of maintaining short positions, depending on the divergence of market opinion.

Short selling is an important tool used by speculators to exploit over-priced securities. Bekaert and Harvey (2000) explore the importance of speculators in emerging market efficiency. They find that the cost of capital, an indicator of market efficiency, decreases after a capital market liberalization. They stress the importance of a regulatory change to a country's openness to speculators - this would naturally extend to short-sales restrictions and thus our work fits naturally into the literature on the globalization of capital markets. Harvey and coauthors have also contributed to our knowledge about skewness in returns, although their findings are not explicitly connected to capital market regulatory changes per se. In a series of studies, Harvey and Sidique (1999, 2000a, 200b) point out that return skewness appears to be priced in both the U.S. and the world capital market. If regulators' believe that short selling regulation can indeed prevent market crises, then Harvey and Sidique' research suggests that 
there should be implications for expected returns and volatility in financial markets around the world.

There are a few key empirical studies that seek to understand the impact of short-sales regulations on return distributions using international data. Aitken et al. (1998) offer evidence from the Australian Stock Exchange suggesting that short sales trades reflect significant bad news about companies. Poitras (2002) concludes that rights issues trade below the arbitrage boundary because of short sale restrictions on the Stock Exchange of Singapore (SES). Biais et al. (1999) use data from the Paris Bourse and show that a market with short-sales constraints reflects good news significantly faster than bad news. Li and Fleisher (2002), using Chinese stock market data, find that the dispersion of domestic analysts' forecasts is negatively correlated to stock returns in the A-share market, where short-sales restrictions are binding, and not significantly related to the return of B-shares where short-sales restrictions are not binding. Studying the impact of short-sales constraints in an international setting avoids potential country specific factors and generalizes the findings on short-sales regulations.

In sum, most theory and empirical evidence from the U.S. and non-U.S. markets suggest that short-sales constraints are an impediment to price discovery-particularly when the news is bad. Some theories argue that limiting short-sales may be necessary under certain conditions to achieve equilibrium, however thus far there is no empirical test of the contrary proposition.

\section{Short-Sales Restrictions Around the World}

Our main data source for short-sales regulation and practice is information provided by investment banks. The Morgan Stanley Dean Witter Global Network Management Division (GNM) has compiled information regarding short-sales regulation, impediments and practices from their global network of sub-custodian banks for 59 countries, and they made a summary of 
this research available to us. We obtained similar information from the International Securities Lending Division at Goldman Sachs (ISL). The ISL complements the information from GNM in two important aspects. It provides detailed information on the tax effects of short positions, the settlement cycle of short sales, and the registration requirements for shorting in 46 countries. There are some countries for which the GNM and ISL data indicates that short selling is not practiced despite the fact that a widely used guide, the Worldwide Directory of Securities Lending and Repo (WDSLP), lists institutional investors involved in short sales in those countries. In these cases, we contacted the listed institutions to understand the discrepancy. In most cases we found they were not active in short sales, or else they were mostly focused on securities lending. An exception is Singapore where it appears that, even though short selling is not formally allowed, it is widely practiced, although short sales are typically executed offexchange between depository agents. We obtained additional information on securities trading, settlement and tax laws from the International Securities Services Association (ISSA) Handbook, however ISSA only provides current information on these issues.

In addition to information provided by investment banks, industry publications and market participants, we contacted the equivalent of the Securities and Exchange Commissions of the 59 countries in the GNM dataset to learn what we could from them about regulation and practice. Information from market regulators was particularly useful in allowing us to track the history of short-sales regulations for each country over the last fifteen years. With their help we are able to examine some key regulatory regime shifts in our empirical analysis. We found in general that the information provided by practitioners was more detailed than the information from regulators, although it should not be surprising that Goldman Sachs and Morgan Stanley Dean Witter know more about market practice than regulators themselves. For instance, in one case, regulators told us that short-selling was not practiced in their market, while ISL indicated 
that most of the short-selling transactions for that market take place offshore-outside the purview of the regulatory agency. What regulators may lack in specific knowledge about market practice they typically make up for in interest in the current project. Many of the regulatory agencies we contacted expressed a strong desire to learn the results of our study, because the question of the efficacy of short-sales restrictions continue to be an issue of interest.

Our information about short-sales regulations and practice is summarized in Table 1. Out of the 59 countries in the GNM dataset, we exclude the countries for which we could not find individual firm stock price data. This leaves a sample of 47 countries. In 35 of them, short selling is currently allowed, at least as of December 2001, the final date of our sample period. In 12 of these 47, short-sales were prohibited for the entire sample period of January, 1990 to December, 2001. In 12 of the 35 countries where short-sales are currently allowed, restrictions existed in 1990 but were lifted at some point within the sample period. These countries are: Chile, Hong Kong, Hungary, Malaysia, New Zealand, Norway, Philippines, Poland, Spain, Sweden, Thailand, and Turkey. In three cases-Malaysia, Hong Kong, and Thailandrestrictions on short selling were removed and later re-enacted gradually. ${ }^{5}$

\footnotetext{
${ }^{5}$ In Malaysia, the Securities Commission issued in December 1995 the Guidelines on Securities Borrowing and Lending, and the Securities Industry Act of 1993 was amended to allow short sales. The regulatory changes came into force on March 7, 1996, and allowed the local exchange-the Kuala Lumpur Stock Exchange-to enact shortselling rules. With that, regulated short selling commenced on September 30, 1996. However, in August 28, 1997 , and in the onset of the Asian financial crises, these activities were suspended as interim measures to prevent excessive volatility in the markets. In February, 2001 the Securities Commission launched a plan-the Capital Market Masterplan - that recommended the re-introduction of short selling and securities lending activities.

In Hong Kong, short selling was prohibited before January 3, 1994. The SEHK then allowed 17 out of the 33 constituent stocks of the Hang Seng Index (HSI) to be sold short subject to several restrictions. These restrictions were lifted on March 25, 1996 at the same time that 113 of the firms listed on the exchange, including all the constituent stocks of the index, were allowed to be sold short.

In Thailand, the Securities Exchange Commission first enforced short-sales regulations on July, 1997, suspending them because of the currency crises. Beginning on January 1, 1998, short sales were allowed again in the Thai capital market, through financial institutions licensed to operate securities borrowing and lending (SBL) business. The practice of short selling has increased gradually: in 1999 there were only three securities companies licensed to operate SBL. Although ISL and GND characterize Thailand as a country where short sales are a common practice, market regulators were aware of only one transaction since 1997, apart from "mistaken" transactions done by brokers.
} 
There is clearly a difference between what the law allows and what is common practice. Although short selling is currently legal in most countries, it is only practiced in 28 . In some countries, tax rules make shorting very difficult. In Chile for instance, although short selling and securities lending have been possible since 1999, they are rarely used because lending is considered an immediate, taxable sale. Given that there is no sale price, the relevant price is the highest price of the stock on the day it is lent; if it is higher than the purchase price, capital gains tax will apply. In Turkey, stock lending is treated as a normal transaction by the tax authorities, and as such it is liable to capital gains tax where applicable. In Finland, transfer laws also place a serious burden on this activity. In countries like the Philippines or Turkey, short selling is allowed, but the rules are not yet clearly defined. In Thailand, evidence of the practice is murky. Regulators in that country believe that short selling is not practiced because the market for borrowing stock is very narrow, especially on the supply side, due to the absence of a futures market.

\section{[Insert Table 1 here]}

There are some other features of short-selling practices throughout the world that are relevant for our purposes. In some markets only the largest and most liquid stocks may be shorted. Until 1996, Hong Kong only allowed short sales in securities specifically designated by the Hong Kong Exchanges and Clearing Ltd. A similar rule currently operates in Greece. More objective criteria are found in Poland, where any security with a market capitalization of at least 250 million zloty qualifies. We adopt the convention of classifying Hong Kong as a country where short selling is allowed only after 1996, even though it was allowed for a subset of stocks beginning in $1994 .^{6}$ For Poland and Greece, GNM reports that short selling is not practiced.

\footnotetext{
${ }^{6}$ See footnote 5 .
} 
We also regard short selling as allowed and practiced in a country even if some investors are prohibited from entering into these transactions. In Sweden, for example, traders can go short without having borrowed the shares in advance, ${ }^{7}$ while individual investors must borrow the shares before they go short. In Greece prior to 2001, short selling was only available to the members of the Athens Derivatives Exchange. Some countries only impose short-sales restrictions on foreign investors. In Brazil, for instance, a short seller must have a domestic legal representative. In India, foreign investors are prohibited from short selling. It is fair to say that for every country in our sample, there exist some constellation of laws, regulations, institutional norms, variation in practice and fine print governing the ability to take and maintain a short position in a stock. Our challenge in this paper has been to categorize them in economically meaningful ways.

Although the actual practice of short selling depends upon laws, regulation, frictions and costs in markets, we are forced to reduce the complexities to a single dimension for purposes of analysis. We classify countries in our sample into four groups, depending on whether short selling is legal and practiced. This classification of course misses the nuances of expenses and risks that potentially characterize differences in short selling across international markets. Never-the-less, even this basic simplification yields interesting results. In the first group we have the countries where short selling became legal some time before 1990, and where short selling is currently practiced. This group includes the U.S., the U.K., Australia, Austria, Belgium, Canada, the Czech Republic, ${ }^{8}$ Denmark, France, Germany, Ireland, Italy, Japan, Luxembourg, Mexico, the Netherlands, Portugal, South Africa, and Switzerland. The second group consists of countries in which short sales were prohibited as of December, 2001. These

\footnotetext{
${ }^{7}$ They must borrow the stock before the end of the day, however.
} 
are: Colombia, Greece, Indonesia, Jordan, Pakistan, Peru, Singapore, the Slovak Republic, South Korea, Taiwan, Venezuela, and Zimbabwe. The third group is comprised of countries in which short selling is allowed but rarely practiced: Argentina, Brazil, Chile, Finland, India, Israel, New Zealand, the Philippines, Poland, Spain, ${ }^{9}$ and Turkey. Finally, the remaining five countries-Hong Kong, Norway, Sweden, Malaysia, and Thailand-comprise a group for which short-sales regulation and practice changed sometime between January, 1990 and December, 2001.

\section{Equity Market Data and Sources}

The international return, volume and issue data for the 47 markets in our study come from Datastream, and our U.S. data come from CRSP. Prices and returns are measured in local currency. We construct value-weighted market indices for each country in the sample. It is important to note that the number of firms per country varies across years, and thus the volatility of the market index might vary with time as a consequence, since there are typically fewer constituent firms in the indices for some countries in the earlier years of the sample. ${ }^{10}$ For this reason we estimate a year-fixed effects model in most of our statistical analysis.

We obtain accounting data from Worldscope for non-U.S. firms, and Compustat for U.S. firms. We also obtain country information from the Economist Intelligence Unit database and from the World Bank. In particular, we characterize each country in our sample by its geographical size, the GDP per capita, and the variance of GDP growth. Finally, we construct an

\footnotetext{
${ }^{8}$ The Prague Stock Exchange was established on November 1992, and the automated trading system started operations in January 1993. We include the Czech Republic in the group of countries where short selling is allowed and practiced, although we only have data on Czech firms since 1993.

${ }^{9}$ Chile made short selling legal only in 2000, but there is no current practice. Spain legalized short selling in 1992 , but only securities lending facilities are common among institutions, as a way of facilitating hedging strategies.

${ }^{10}$ Datastream has an acceptable coverage only after 1995.
} 
index of good government following MYY, as the sum of indices of corruption, risk of government repudiation of contracts, and risk of expropriation of private property in La Porta et al. (1997).

\section{Short-Sales Restrictions and the Co-movement of Stock Returns}

The first question in our analysis is whether short-sales restrictions play a role in efficient price discovery. The key implication of Diamond and Verecchia (1987) for example, is that short-sales constraints impede the market's ability to rapidly impound value-relevant information. As the voluminous literature on the efficient market theory suggests, there is no universal test for relative market efficiency, although event studies and filter rules have a long history of application. An important recent contribution to the literature on market efficiency is MYY's observation that more efficient markets can be expected to have more idiosyncratic risk, since the ratio of firm-specific information to market-level information is likely to be higher in informational environments that allow market participants to acquire information and act quickly and inexpensively upon it. MYY examine international differences in the degree of comovement in stock prices across countries around the world, and find that the ratio of idiosyncratic risk in relatively developed markets is higher than in markets that are commonly viewed as less developed-particularly emerging markets. In our analysis, we use the MYY measure as a proxy for market efficiency, and then test whether cross-sectional differences in short-sales constraints correlate well to it.

\section{a. Measures of Price Synchronicity}

Following MYY, for each country in our sample and for every year, we calculate two aggregate measures of individual security co-movement. 
We compute the ratio:

$$
f_{i t}=\frac{\max \left\lfloor n_{i t}^{u p}, n_{i t}^{\text {down }}\right\rfloor}{n_{i t}}
$$

where $n_{i t}$ is the number of stocks in country $i$ and week $t, n_{i t}{ }^{\text {up }}$ is the number of stocks whose price rise in week $t$, and $n_{i t}{ }^{\text {down }}$ is the number of stocks whose price fall. We then average the f's across countries and years, that is:

$$
f_{i T}=\frac{\sum_{t=1}^{\delta_{i T}} f_{i t}}{\delta_{i T}}
$$

where $\delta_{\mathrm{iT}}$ is the number of trading weeks in country $\mathrm{i}$ and year T. The ratio of stocks moving together varies between 0.5 and 1 , numbers closer to 1 indicate more co-movement. MYY argue that more co-movement implies less efficient price discovery in the market, since stock specific information is presumably the driver of any deviation in co-movement among stocks. Thus, cross-sectional idiosyncratic risk is another potential way to capture this intuition. We thus also compute the $\mathrm{R}^{2}$ for regressions of the form:

$$
r_{i j t}=\alpha_{i j}+\beta_{i} r_{m j t}+\varepsilon_{i j t}
$$

That is, we regress weekly stock returns on the value-weighted market return, for every firm i and in every year (where week $t$ belongs to year $T$ ). We then average the $R^{2}$ s for each country $j$ and for every year T, as in MYY:

$$
R_{j T}^{2}=\frac{\sum_{i} R_{i j T}^{2} S S T_{i j T}}{\sum_{i} S S T_{i j T}}
$$

where SST is the sum of squares in regression (3). 
MYY find that developing economies display significantly higher levels of comovement than more developed ones. In particular, they find that co-movement is explained in the cross-section by the GDP per capita. They provide several hypotheses why this can happen, and show that, when interacted with an index of good government, the significance of the GDP per capital disappears.

One potentially important explanation for such a pattern is that smaller countries have less-diversified stock markets. To address this issue, MYY use country-level and industry-level Herfindahl indices. The former captures the cross-industry concentration based upon sales, the latter captures the average within-industry concentration based upon sales. To see how this might work, consider some extreme examples: Finland and Norway vs. the U.S. In Finland, Nokia represents more than $50 \%$ of the market capitalization of the Helsinki Stock Exchange. In terms of domestic sales, the telecommunications giant accounts for $5 \%$ of the total sales in the country, and $19.6 \%$ of the sales in its industry. Indeed, Telecom Equipment accounted for $22.82 \%$ of the total sales of Finnish companies.

The country-Herfindahl index for Finland is 12.28. This is not dramatically higher than the a median of 11.02 for all the countries in the sample. The industry-Herfindahl index for Finland is 8.29 (compared to a median 7.11 for the whole sample). This means that, even though the telecom industry is highly concentrated, the other industries are not. In contrast, Norway, has a country-Herfindahl measure of 73 , and an industry-Herfindahl measure of 17.82 . In this case it is driven by the natural resources industries that represent the bulk of the industrial production in Norway. For the U.S., the country-Herfindahl measure is 4.45 in 2001, and the industry-Herfindahl measure is $2.25 \%$. Thus, Norway has a low cross-sectional dispersion in firm returns due to its industrial structure, not necessarily because of relative market efficiency, and the Herfindahl indices appear to be a useful control. 
In our analysis, we replicate as closely as possible the estimation and control variables used in MYY, adding a short-sales indicator variable. We construct indices of industry concentration (by industry and country, as described in their paper), indices of earnings comovement, ${ }^{11}$ and calculate the number of listed firms in each country and year. The shortsales indicator is a dummy variable that equals one whenever short selling is allowed and practiced in a given country and year, and zero otherwise. If a country changed its regulation in a given year, we eliminate that observation from the sample. Our final panel with complete data includes 503 observations. The earnings co-movement index is available for only a subset of countries. When we use it the number of observations is reduced to 268 . We estimate the model with year-fixed effects and country-fixed effects. We control for several country-and-year specific factors, such as the GDP per capita, the country and industry Herfindahl indices and the earnings co-movement index. Whenever country-fixed effects are not used, we additionally control for time-invariant variables, like the geographical size of the country, the variance in GDP growth, and the good government index. As in MYY, the dependent variable is transformed into a continuous variable over the range $[-\infty,+\infty]$. We report the results of the estimation in Table 2.

\section{[Insert Table 2 here]}

\section{b. Results}

The first panel in Table 2 replicates the MYY results, although our sample is significantly different in time and cross-section from theirs. Despite these sample differences, we generally confirm the MYY finding that countries with higher GDP per capita display lower

\footnotetext{
${ }^{11}$ Since we replicate the procedure in MYY, we do not provide details on how these variables are computed.
} 
stock price synchronicity. The only exception is that in our first specification with both country- and year-fixed effects, the coefficient on log-GDP per capita is positive and significant. In this case, the GDP per capita must be interpreted strictly in a time-series sense: stock price co-movement increases in a country as its GDP per capita grows. The economic interpretation of this positive relationship is not clear, however the sign on GDP becomes negative as we eliminate either country- or year-fixed effects in other specifications. The good government index is also statistically significant, with two caveats: (i) the coefficient displays different signs depending on the specification, and (ii) the GDP per capita does not become insignificant once the good government index is introduced in the regression. We suspect these differences are due to the larger cross-section of countries we use in our analysis, but they could also be due to the fact that there have been secular changes in the residual risk component in different countries. In recent years, Campbell, Lettau, Malkiel and Xu (2001) for example, note a dramatic downward shift in residual risk for the U.S. If other countries experienced similar trends in residual risk, then the cross-sectional correlation to other variables could certainly change.

The second panel in Table 2 shows that lifting short-sales restrictions is associated with an increase in the idiosyncratic portion of stock returns. The coefficient on the short-sales indicator is negative and significant at the 1 percent level or more in each specification. This result is evidently not driven by country differences. That is, the description of legal regimes in Section III shows that, in general, more developed markets allow short selling while developing markets restrict it. However, the short-selling indicator remains significant when we allow for both year- and country-fixed effects. This is possible because we have inter-temporal changes in short-sales practices for some countries in our sample. Moreover, the short-sales indicator is 
significant after controlling for differences in the GDP per capita across countries, and the number of listed firms.

We perform a similar analysis with the $\mathrm{R}^{2} \mathrm{~s}$ of the regressions of stock returns on market indices. These results are reported in Table 3. Following MYY, we have transformed the $\mathrm{R}^{2} \mathrm{~s}$ to map them to the set of real numbers. The short-sales indicator is significant and has a negative coefficient in all specifications, except when country- and year-fixed effects are estimated. The differences between Table 2 and Table 3 may be due to the non-parametric nature of the synchronicity measure. Although it does not capture magnitude differences in residual risk, it is presumably robust to extreme outliers. Using $\mathrm{R}^{2} \mathrm{~s}$, the GDP per capita becomes insignificant once we include the short-sales indicator. However, the good government index is either unable to eliminate the significance of the GDP per capita, or displays a positive coefficient, which contradicts the findings of MYY. Only when the earnings co-movement index enters the last regression in the bottom panel in Table 3 do both the government index and the GDP per capita become insignificant.

\section{[Insert Table 3 here]}

In economic terms, a coefficient of -0.431 for the indicator means that for the average country, the removal of short-selling restrictions reduces the $\mathrm{R}^{2}$ of the average stock by $27 \%$. In other words, the idiosyncratic risk of the average stock increases by $27 \%$. As we show, this result is robust to country differences, different time periods, and institutional differences. An economic rationale for our findings is provided by Campbell et al. (2001), who observe that the proportion of idiosyncratic risk in the U.S. has increased significantly in recent years. Despite the analyst scandals characterizing the post-Enron U.S. market, they suggest the trend towards more residual risk may result from the increasing availability of value-relevant firm-specific information which may in turn be impounded into stock prices in a liquid market. 


\section{Short-Sales Restrictions and the Distribution of Stock Returns}

In this section we examine the distribution of stock returns conditional upon short-sales restrictions. We compute statistics for three different series' for each country. First we construct weekly stock returns for each firm in our sample with at least 100 daily observations available in a given year. We also construct time series' of weekly returns for the corresponding market indices. Finally, we run, for every year and each firm, regressions specified in equation (3), and save the residuals from the regression as abnormal firm returns. In a market with many systematic shocks, firms' raw returns may primarily reflect systematic shocks and thus the residual may be of interest. Because equity returns are distributed approximately log-normal, we transform the three groups of returns into their logarithmic representation, and compute the skewness, standard deviation, and frequency of extreme returns.

We find weak evidence that supports regulators' view that short-selling constraints help prevent financial panics, at least for individual securities. The distribution of individual stock returns in our sample are less negatively skewed when short-selling is prohibited. There is also a significantly lower chance of a negative extreme return when short-selling is prohibited. Both findings offer some support that short-selling regulations prevent extreme negative returns. However, we find little evidence that short-sales constraints reduce the negative skewness of market level returns.

\section{A. Skewness}

Hong and Stein (2002) develop a model in which investors possess different information about the value of a stock. Investors with negative information cannot always use it due to 
short-sale constraints. They would be willing to sell the stock to high-valuation investors, but they do not necessarily own it. The Hong and Stein model provides a rationale for why stock returns display negative skewness. Their paper predicts that elevated trading volume should be associated with increased negative skewness. Indeed, in the accompanying empirical study, Chen et al. (2002) test the proposition that abnormal turnover is a predictor of negative skewness. They find consistent evidence on a sample of NYSE and AMEX stocks for the period July, 1962 to December, 1998: at the firm level, changes in turnover predict future negative skewness.

A reasonable implication of the Hong and Stein model is that whenever short-selling restrictions are removed, skewness should be become less negative. Our objective in this section is to test this proposition. Given that skewness is almost certainly affected by country- and time-specific effects, we perform a cross-sectional analysis that controls for these factors. In addition to the country-specific controls, we follow Chen et al. (2001), who find that the detrended turnover and past market returns are predictors of skewness. We construct the average de-trended turnover for the countries in our sample as follows. We first calculate the de-trended volume by firm, by subtracting the previous-year volume from the current volume. ${ }^{12}$ We then calculate the sum of de-trended volumes for all firms in a given country and year, and divide by the total number of shares outstanding for all the firms in the country with available data on volume. $^{13}$

Results from the estimation are in Table 4. Interestingly, we find that short-sales restrictions are associated with less negative, not more negative skewness. The short-sales indicator explains the skewness of raw and market-adjusted individual stock returns. However

\footnotetext{
${ }^{12}$ Note that we lose one year of observations for every firm.

${ }^{13}$ We try an alternative specification that consists of calculating the market turnover first, and then de-trending it. This methodology, similar to Chen et al. (2001), provides qualitatively similar results.
} 
the evidence for the market itself in each country is insignificant once control variables like size are added. ${ }^{14}$ We also find that, without controlling for short-sales restrictions, less developed countries, i.e. those with lower GDP per capita, have more positively skewed returns. However, the significance of the coefficient disappears once we control for short selling.

[Insert Table 4 here]

In sum, for markets in which short selling is either prohibited or not practiced, there is no evidence that returns display significantly less negative skewness at the individual stock level. However, at the market level, where the welfare effects are greatest and where regulators expect short-sales to reduce crashes, it makes little difference whether short sales are allowed and practiced, once we control for macroeconomic factors.

In addition to these results we find some evidence consistent with the theoretical model in Hong and Stein (2002) in that differences of opinion, proxied by the lagged de-trended turnover, predict more negative skewness. We also find weak evidence that lagged market returns help predict negative skewness. The coefficient on lagged market returns is negative and significant only when the dependent variable is the skewness of raw returns.

\section{B. Volatility of Returns}

In Table 5 we study the effect of short-sales restrictions on the volatility of individual stock returns. We calculate the average standard deviation of individual stock returns, and use its logarithm as endogenous variable in the regressions, hence it can take any real value. As usual, we employ country- and time-specific variables

\section{[Insert Table 5 here]}

\footnotetext{
${ }^{14}$ In a specification that does not control for year and GDP effects we find a significant association between short-
} 
The coefficient for the short-sales indicator is always negative and significant at the 1 percent level-consistent with the association of short-sales restrictions and higher return volatility-except for the case in which we use country- and year-fixed effects. Returns are more volatile in less developed countries, but the significance of the result disappears once we control for the good government index. In that regard, better-governed countries display lower return volatility. Returns are also less volatile in countries with less volatile fundamentalsmeasured by the variance in GDP growth and the earnings co-movement index. In general, our analysis of the cross-sectional differences in the volatility of returns conditional upon shortselling restrictions should be considered in light of the potential that any association uncovered between the two might be driven by reverse causality. Riskier markets in general are more likely to pose concerns for regulators whose goals presumably include investor protection.

\section{Crashes \\ C.1. Sample of All Countries}

Arguably the most important rationale for short-sales restrictions is that short selling is responsible for recent market crashes in the world financial market-particularly the 1987 market crash and the 1997 Asian crisis. Our objective in this section is to evaluate the empirical evidence for such a view.

The main difficulty in estimating the probability and severity of a market crash conditional upon the existence of short-sales restrictions is the Peso problem: we only have data on realized crashes. One alternative is to measure the extent of market drops during crisis events depending upon the existence of short-selling restrictions. However, this would not answer the

sales restrictions and a reduction in negative market skewness. We do not report these results in a table. 
question of whether crashes are more likely in the presence of short-sellers. If we believe market regulators, short selling may not trigger a crash, but simply make it more severe.

We therefore calculate the number of days in our sample period in which stock returns are below two standard deviations from their previous year average. We divide this number by the total number of trading days, and then compute the frequency of extreme returns. Under the assumption that returns are log-normally distributed, the percentage should equal 2.5 percent.

\section{[Insert Table 6 here]}

In Table 6 we regress the frequency of extreme results on a set of explanatory variables. We do not include the number of listed firms as an explanatory variable because the denominator in the frequency calculation is the number of trading days per year times the number of listed firms in a given country and year. Therefore, there is an almost exact linear relationship between a log transformation of the frequency of extreme events, and the log of the number of listed firms.

In Table 6, short-sales restrictions are only weakly and insignificantly associated with more frequent extreme negative returns. None of the explanatory variables, except for the shortsales indicator, display a positive coefficient. There is only once specification for which we reject the null. This is the case in which we use a sub-sample of country-years for which we have data on earnings co-movement. The evidence from this table suggests that the probability of extreme negative returns is not likely to be a function of short-sales practices in countries, but rather determined by other non-specified, country-specific factors. 


\section{C.2. Countries with Regulatory Changes}

To shed some light on the relationship between short-sales constraints and extreme returns, and in order to eliminate a number of the potential cross-sectional differences that might explain the results thus far, we restrict our attention to the sub-set of countries that changed regulations over the period 1990-2001. Essentially this should allow a good hedonic control, country by country, at least under the assumption that the regulatory change is not triggered by shifts in other characteristics. These countries are Hong Kong, Norway, Sweden, Malaysia, and Thailand. In the case of Hong Kong, Norway, Sweden, and Thailand, short-selling restrictions were removed in a specific year (not the same calendar year for each country). In Malaysia—as we detail in section III—short selling was allowed only for the period 1995-1997, and was then prohibited again in 1997 at the onset of the Asian financial crises.

\section{[Insert Table 8 here]}

Table 8 reports the frequency of extreme events for the five countries, around the year in which short sales become effective. We calculate the average by year-to-event, ${ }^{15}$ and find that, on average, the frequency of extreme returns is 3.69 percent one year after restrictions are lifted. In some years, however, extreme returns are too frequent $(7.28$ percent year $t+5,7.10$ percent in year $\mathrm{t}+6)$. In Norway, Malaysia, and Hong Kong, extreme returns are more frequent in all but one of the periods, compared to period $\mathrm{t}-1$, in which short sales are allowed. In Sweden, the frequency of extreme results is higher after 1991 than in 1990, one year before the lifting of short-selling restrictions. However, in Thailand the effect of short sales is a reduction of the percentage of extreme returns, compared to the pre-1997 period. It therefore seems that the effect of short sales on crashes may be somewhat country-specific.

\footnotetext{
${ }^{15}$ Malaysia is not included in years after $t+2$, because short sales were prohibited again in 1997 .
} 
Cross-sectional regression results using yearly information for the aforementioned five countries are reported in Table 8. We employ the same controls in these regressions as in previous sections. The power of the results declines substantially as expected, since we have only 45 observations. Unlike the previous estimates, we find that the frequency of extreme declines is marginally associated with relaxation of short-sales constraints. The coefficient on the short-sales indicator is significant at the 10 percent level in two of the specifications when we do not use country-fixed effects. It also has a time-series interpretation. The lifting of short-sales restrictions results in an average increase in the frequency of extreme returns. When we estimate the regression with country- and year- fixed effects (the first model), we find some support for the hypothesis that short sales increase the probability of a crisis. We certainly find no evidence in favor of a positive relationship between short-sales restrictions and severity of market crashes.

\section{[Insert Table 8 here]}

\section{Kernel Estimation of Return Distributions}

Thus far, we have looked at various statistics of conditional distributions. It is instructive, however, to look at the return densities themselves. We perform a kernel estimation of a density functions of stock returns with and without short-sales constraints that fits the distribution of returns. ${ }^{16}$ The advantage of the kernel estimation is that we do not need to constrain the distribution to be normal, or even symmetric.

\footnotetext{
${ }^{16}$ The general form of the kernel density estimator is:

$$
\hat{f}_{\lambda}(x)=\frac{1}{n_{\lambda}} \sum_{i=1}^{n} N\left(\frac{x-x_{i}}{\lambda}\right)
$$
}


[Insert Figure 2 here]

We estimate the kernel density for the market returns, both for the total sample and for the sub-sample of countries with regulatory changes. Figure 2 plots the histograms of returns, as well as the densities, depending on the existence of short-selling restrictions. Confirming the results in Table 4, Figure 2 shows that (i) the distribution of returns is more leptokurtotic when short sales are allowed and practiced.; and (ii) the distribution of returns is not symmetric.

\section{Conclusions}

Restrictions on short selling of shares are nearly as old as stock markets themselves. Critics often view short-sales as immoral-the exploitation of others' misfortune and an exacerbating factor in periods of market crisis. As recently as the Asian currency crisis of 1997, short-sellers were blamed by politicians and journalists for helping to destroy the "Asian Miracle." In the current environment with the growth of hedge funds, concerns about the danger of allowing speculation frequently surface. There is at least some common suspicion that short selling can exacerbate market crashes. Most academic researchers, however, make a strong theoretical case for allowing short-sales in markets. Their case is based upon the notion that markets exist to facilitate the efficient pricing of assets, and that restricting short-sales reduces

where $\mathrm{N}(\cdot)$ is the kernel function, that we specify to be standard normal, $\lambda$ is the bandwidth parameter, $\mathrm{n}$ is the sample size, and xi is the ith observation. The kernel density minimizes the mean integrated squared error $\eta \lambda$ :

$$
\eta_{\lambda}=\int_{x}\left\{E\left(\hat{f}_{\lambda}(x)-f(x)\right)^{2}\right\} d x+\int_{x} \operatorname{Var}\left(\hat{f}_{\lambda}(x)\right) d x
$$

where $\lambda$ is the one that minimizes the estimated mean integrated square error:

$$
\hat{\eta}_{\lambda}=\frac{1}{4} \lambda^{4}\left(\int_{t} t^{2} N(t) d t\right)^{2} \int_{x}\left(f^{\prime \prime}(x)\right)^{2} d x+\frac{1}{n \lambda} \int_{t}(N(t))^{2} d t
$$


market efficiency. Recent empirical evidence by researchers, particularly Jones and Lamont (2001) provides some support for the hypothesis that difficulty in short selling is associated with security mispricing. In this paper, we survey short-selling regulations and practices for major stock markets around the world. We find empirical evidence in support of both views. Using a market efficiency measure developed by Mørck et al (2000), we find a negative association between short-sales restrictions and the diffusion of value-relevant information into prices. Our analysis of the statistical characteristics of markets, specifically the standard deviation and skewness of log returns, suggests that short-sales restrictions are more common in highvolatility countries, but that the restrictions are also weakly associated with less negative skewness in individual stock returns. 


\section{References}

Aitken, Michael, Alex, Frino, Michael S. McCorry, and Peter L. Swan, 1998, Short Sales Are Almost Instantaneously Bad News: Evidence from the Australian Stock Exchange, Journal of Finance, 2205-2223

Allen, Franklin, and Douglas Gale, 1991, Arbitrage, Short Sales, and Financial Innovation, 1991, Econometrica 59(4), 1041-1068

Bekaert, Geert, and Campbell Harvey, 2000, Foreign Speculators and Emerging Equity Markets, Journal of Finance, 565-613

Bernardo, Antonio, and Ivo Welch, 2002, Financial Market Runs, working paper, Yale School of Management, New Haven, CT

Biais, Bruno, Christophe Bisiere, and Jean-Paul Decamps, 1999, Short-sales constraints, Liquidity and Price Discovery: An Empirical Analysis on the Pris Bourse, European Financial Management 5(3), 395-409

Campbell, John Y., Martin Lettau, Burton G. Malkiel and Yexiao Xu , 2001, "Have Individual Stocks Become More Volatile? An Empirical Exploration of Idiosyncratic Risk," Journal of Finance 56(1), 1-43

Chen, Joseph, Harrison Hong, and Jeremy Stein, 2001, Forecasting Crashes: Trading Volume, Past Returns, and Conditional Skewness in Stock Prices, Journal of Financial Economics 61(3), 345-381.

Chen, Zhiwu, 1995, "Financial Innovation and Arbitrage Pricing in Frictional Economies," Journal of Economic Theory, 65(1), February, 117-135.

Chen, Zhiwu, 2001, "Viable Costs and Equilibrium Prices in Frictional Securities Markets," Annals o Economics and Finance, 2(2), 297-323.

D'Avolio, Gene, 2002, The Market for Borrowing Stock, Journal of Financial Economics, 66(2), pages 271-306.

De Marchi, Neil and Paul Harrison, 1994, "'Trading in the Wind' with Guile: The Troublesome Matter of the Short Selling of Shares in Seventeenth Century Holland," History of Political Economy Supplement, 26(0), pages 47-65. 
Diamond, Douglas, and Robert Verrecchia, 1987, Constraints on Short-selling and Asset Price Adjustment to Private Information, Journal of Financial Economics 18(2) June, 277-311

Dillen, J.G. van, 1930, Isaac Le Maire en de Handle in Action der Oost-Indische Companie," Economisch-historisch Jaarboek.

Duffie, Darrell, Nicholae Garleanu, and Lasse Heje Pedersen, 2002, Securities Lending, Shorting and Pricing, Journal of Financial Economics 66(2), pages 307-339.

Erzo G. J. Luttmer, 1996, Assessing Specification Errors in Stochastic Discount Factor Models, Econometrica 64(6), 1439-1467.

Geczy, Christopher C., David K. Musto, and Adam V. Reed, 2002, Stocks Are Special Too: An Analysis of the Equity Lending Market, Journal of Financial Economics 66, 241-269.

Harvey, Campbell, and Akhtar Siddique, 1999, autoregressive Conditional Skewness, Journal of Financial and Quantitative Analysis 34, 465-487

Harvey, Campbell, and Akhtar Siddique, 2000a, Conditional Skewness in Asset Pricing Tests, Journal of Finance 55, 1263-1295

Harvey, Campbell, and Akhtar Siddique, 2000b, Time-Varying Conditional Skewness and the Market Risk Premium, Research in Banking and Finance 1, 27-60

He, Hua, and David Modest, 1995, Market Frictions and Consumption-based Asset Pricing Journal of Political Economy, 103(1), 94-117.

Hong, Harrison and Jeremy Stein, 2002, Differences of Opinion, Short-sales Constraints and Market Crashes, forthcoming Review of Financial Studies.

International Securities Services Association Handbook, 2002.

Jegadeesh Naramsimhan and Sheridan Titman, 1995, Overreaction, Delayed Reaction and Contrarian Profits, Review of Financial Studies 8, 973-993.

Jouini, E and H, Kallal 2001, Efficient Trading Strategies in the Presence of Market Frictions, Review of Financial Studies 14(2), 343-369 
Jones, Charles and Owen Lamont, 2002, Short Sale Constraints and Stock Returns, Journal of Financial Economics, 66(2), 207-239.

La Porta R., Lopez-de-Silanes, Shleifer, A., Vishny, R.W., 1997, Law and Finance, Journal of Political Economy 106, 1112-1155.

Lars Peter Hansen and Ravi Jagannathan, 1997, Assessing Specification Errors in Stochastic Discount Factor Model, Journal of Finance, 52(2) June, 557-590.

Li, Lianfa, and Belton M. Fleisher, 2002, Heterogeneous Expectations and Stock Prices in Segmented Markets: Application to Chinese Firms, working paper, Ohio State University.

Montias, John Michael, 1989, Vermeer and His Milieu, Princeton Press, Princeton, NJ.

Mørck, Randall, Bernard Yeung, and Wayne Yu, 2000, The Information Content of Stock Markets: Why do Emerging Markets Have Synchronous Stock Price Movement, Journal of Financial Economics, 58(1), pages 215-260.

Ofek, Eli, and Matthew Richardson, 2002, DotCom Mania: The Rise and Fall of Internet Stock Prices, Journal of Finance, forthcoming.

Poitras, Geoffrey, 2002, Short Sales Restrictions, Dilution and the Pricing of Rights Issues on the Singapore Stock Exchange, Pacific Basin Finance Journal 10(2), 141-62.

Ross, Stephen A., 1976, “The Arbitrage Theory of Capital Asset Pricing," Journal of Economic Theory 13, 341-360.

Untermyer, Samuel, 1915, Speculation on Stock Exchanges and Public Regulations of the Exchanges, American Economic Review 5(1), 24-68.

World Directory of Securities Lending and Repo, International Securities Finance Magazine. 


\begin{tabular}{|c|c|c|c|c|}
\hline Country & $\begin{array}{l}\text { When was short } \\
\text { selling allowed }\end{array}$ & $\begin{array}{l}\text { When was securities } \\
\text { lending allowed }\end{array}$ & $\begin{array}{l}\text { Whether Short } \\
\text { Selling is } \\
\text { Practiced }\end{array}$ & Comments \\
\hline Argentina & 1999 & 1991 & No & Equity lending is rare and occurs only between brokers. Short-selling cannot last more than 360 days in a row. Only allowed for 16 stocks. \\
\hline Australia & Before 1990 & Before 1990 & Yes & $\begin{array}{l}\text { Securitites can be borrowed from ASX and counter party. Cash and non-cash collateral are accepted at 105-110\% of the underlying value of the loan } \\
\text { securtities. Collateral is marked-to-market daily. }\end{array}$ \\
\hline Austria & Before 1990 & Before 1990 & Yes & \\
\hline Belgium & Before 1990 & Before 1990 & Yes & $\begin{array}{l}\text { There is no organized market for stock lending and borrowing. A law on securrities lending was passed in March } 1999 \text { but still pending. There is no official } \\
\text { regulation on short selling stocks. }\end{array}$ \\
\hline Brazil & Before 1990 & Before 1990 & No & 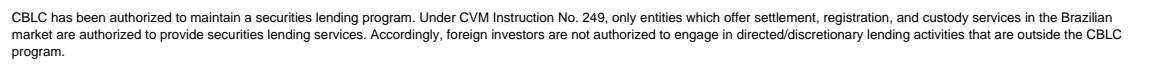 \\
\hline Canada & Before 1990 & Before 1990 & Yes & The market for securities lending is large (40+ billion dollar business ) and well developed. \\
\hline Chile & Allowed in 1999 & Allowed in 1999 & No & $\begin{array}{l}\text { Short-selling cannot last more than } 360 \text { days in a row. The entity (including individuals) who is lending the stocks maintains the beneficial ownership, except } \\
\text { the right to vote. }\end{array}$ \\
\hline Colombia & Not allowed & Not allowed & No & Securities lending is not authorized. \\
\hline Czech Republic & Before 1990 & Before 1990 & Yes & $\begin{array}{l}\text { There is no regulations on short selling since Prague Stock Exchange (PSE) was opened in 1993. IT is possible to sell securities only if absent securities are } \\
\text { bought or borrowed before the settlement date. }\end{array}$ \\
\hline Denmark & Before 1990 & Before 1990 & Yes & No regulatory barriers inhibiting securities lending. \\
\hline Finland & Allowed in 1998 & Before 1990 & No & The transfer tax laws place a serious burden on the activity. \\
\hline France & Before 1990 & Before 1990 & Yes & $\begin{array}{l}\text { Securities lending is permitted by law in } 1987 \text { and 1988. All establishments (domestic and foreign) are eligible for short-selling as long as they are } \\
\text { recognized as counter parties. }\end{array}$ \\
\hline Germany & Before 1990 & Before 1990 & Yes & A securities lending facility was created in 1989 to improve market liquidity. \\
\hline Greece & Not allowed & Not allowed & No & Securities lending and borrowing have been legalized by the Greek Parliament but the operational framework has yet to be established. \\
\hline Hong Kong & Allowed in 1996 & Before 1990 & Yes & Short selling is allowed for 33 stocks in 1994, and then to a wide range of stocks in 1996. \\
\hline India & Before 1990 & Before 1990 & No & Not popular among market players. Not allowed for foreign investors. \\
\hline Indonesia & Not allowed & Allowed in 1996 & No & No guidelines have been provided by BAPEPAM, The Indonesian Regulatory Authority for the Indonesian Capital Market. \\
\hline Ireland & Before 1990 & Before 1990 & Yes & Securities lending volume is still limited. \\
\hline Israel & Before 1990 & Before 1990 & No & $\begin{array}{l}\text { The TASE does not offer a securtities lending program to its members. TASE rules indicate that the securities account of a TASE member at clearing house } \\
\text { may not enter into a short position intentionally. }\end{array}$ \\
\hline Italy & Before 1990 & Before 1990 & Yes & \\
\hline Japan & Before 1990 & Before 1990 & Yes & Allowed for stocks listed on the first section of the exchanges. \\
\hline Jordan & Not allowed & Not allowed & No & \\
\hline Luxembourg & Before 1990 & Before 1990 & Yes & \\
\hline Malaysia & $\begin{array}{l}\text { Allowed in } 1995 \text {, Prohibited } \\
\text { again in } 1997\end{array}$ & $\begin{array}{l}\text { Allowed in } 1995 \text {, Prohibited } \\
\text { again in 1997 }\end{array}$ & Yes & $\begin{array}{l}\text { Short seling and securities lending were suspended during the regional financial crisis of 1997. With the economic recovery, improvements in report } \\
\text { requirements, prudential controls and the cessation of trading of KLSE-listed seccurities offshore, short selling and securities lending are expected to be } \\
\text { restored restored. }\end{array}$ \\
\hline Mexico & Before 1990 & Before 1990 & Yes & $\begin{array}{l}\text { The system is generally used as a safeguard against failing to deliver rather than securities lending as a product. Foreign investors are eligible to participate } \\
\text { in securtities lending through a local broker. Margin is } 150 \% \text {. }\end{array}$ \\
\hline Netherlands & Before 1990 & Before 1990 & Yes & There is a central lending facility at the ASE. \\
\hline New Zealand & Allowed in 1992 & Not allowed & No & Tax regulations prevents onshore securtities lending from taking off. \\
\hline
\end{tabular}




\begin{tabular}{|c|c|c|c|c|}
\hline Country & $\begin{array}{l}\text { When was short } \\
\text { selling allowed }\end{array}$ & $\begin{array}{l}\text { When was securities } \\
\text { lending allowed }\end{array}$ & $\begin{array}{l}\text { Whether Short } \\
\text { Selling is } \\
\text { Practiced } \\
\end{array}$ & Comments \\
\hline Norway & Allowed in 1992 & Allowed in 1996 & Yes & Securities lending is still in the early stages of development and tax implications are being discussed at the Ministry of Finance. \\
\hline Pakistan & Not allowed & Not allowed & No & There are no regulations that restrict foreign investors from lending or borrowing securities. Short selling is not allowed. \\
\hline Peru & Not allowed & Not allowed & No & $\begin{array}{l}\text { Off shore lending is prohibited. Lima Stock Exchange is considering allowing new activities such as securrities lending, short selling and new repo trades in } \\
\text { the future. }\end{array}$ \\
\hline Philippines & Allowed in 1998 & Allowed in 1998 & No & Although the SEC has approved the rules on SBL and short selling, the rules are not yet clearly defined in the market. \\
\hline Poland & Allowed in 2000 & Before 1990 & No & Neither the full legal nor operational framework have been established. \\
\hline Portugal & Before 1990 & Before 1990 & Yes & Securities lending is allowed and practiced. BVLP charges 10 b.p. annualized over the initial value (maximum days for calculation is 45 ) for this service. \\
\hline Singapore & Not allowed & Before 1990 & Yes & Onshore lending is limited while offshore lending is active. \\
\hline Slovak Republic & Not allowed & Not allowed & No & Securities lending and borrowing is not allowed under the Securities Act. \\
\hline South Africa & Before 1990 & Before 1990 & Yes & Short selling is always allowed in JSE. \\
\hline South Korea & Not allowed & Before 1990 & No & Securities lending and borrowing has not been active to date. \\
\hline Spain & Allowed in 1992 & Allowed in 1992 & No & $\begin{array}{l}\text { Securities lending and short selling is available since } 1992 \text {. Since July } 1994 \text {, SCLV has acted as principal for the lending pool formed by the daily bids from } \\
\text { the clearing members. The load must be reported to the SCLV within two working days of the sale date. }\end{array}$ \\
\hline Sweden & Allowed in 1991 & Allowed in 1991 & Yes & Widely practiced. \\
\hline Switzerland & Before 1990 & Before 1990 & Yes & $\begin{array}{l}\text { Securities lending is legal in Switzerland and there are no restrictions on who may borrow or lend. There is no central lending facility and no stamp duties } \\
\text { apply to securities lending. }\end{array}$ \\
\hline Taiwan & Not allowed & Not allowed & No & Foreign investors are prohibited from borrowing securities on-shore and can only lend securrities on-shore to brokers to cover their fails. \\
\hline Thailand & Allowed in 1997 & Allowed in 1999 & Yes & Short selling is very limited after being allowed in 1999. \\
\hline Turkey & Before 1990 & Allowed in 1996 & No & Securtities lending is not widely practiced. \\
\hline United Kingdom & Before 1990 & Before 1990 & Yes & Short selling is active in UK. \\
\hline United States & Before 1990 & Before 1990 & Yes & \\
\hline Venezuela & Not allowed & Not allowed & No & $\begin{array}{l}\text { Securities lending is not specilically prohibited or provided for under current regulations. Free transfers of securities between different beneficial owners } \\
\text { cannot be done without executing a trade on the exchange. Off-shore lending is generally not practiced. }\end{array}$ \\
\hline Zimbabwe & Not allowed & Not allowed & No & \\
\hline
\end{tabular}

Table 1. Short Selling Restrictions Around the World

For each country in the sample, the table describes the date where short selling was allowed if this happened on or after 1990.

Otherwise countries are classified as 'Allowed Before 1990', or 'Not Allowed'. Securities Lending refers to the ability of an

investor to borrow securities from another party. Short Selling refers to the ability of an investor to sell a borrowed security to a
third party. Short Selling is practiced when there are indications from market participants, market regulators, or institutions

third party. Short Selling is practiced when there are indications from market participants, market regulators, or institutions
within a country, that short selling is a common practice. Data is obtained from the Global Network Management Division at

Morgan Stanley Dean Witter, the International Securities Lending at Goldman Sachs, the corresponding market regulators, the

International Securities Services Association Handbook, and practitioners listed in the Worldwide Directory of Securities

Lending and Repo. 


\section{Dependent Variable}

Number of Observations

Adjusted R-squared

Year Fixed Effects

Country Fixed Effects

\section{Short Selling is Allowed and Practiced}

\section{Log (Number of Firms)}

Log (GDP per capita)

Country Herfindahl Index

Industry Herfindahl Index

Log (Country Size)

Variance in GDP growth

Earnings Comovement Index

Good Government Index

\section{Dependent Variable}

Number of Observations

Adjusted R-squared

Year Fixed Effects

Country Fixed Effects

Dependent Variable : Average Fraction of Stocks Moving Together

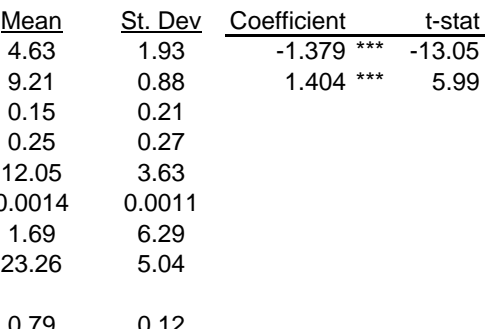

\begin{tabular}{|c|c|c|c|c|c|}
\hline Coefficient & t-stat & Coefficient & t-stat & Coefficient & t-stat \\
\hline$-0.260^{* \star *}$ & -9.88 & $-0.134^{\star \star *}$ & -4.55 & -0.017 & -0.51 \\
\hline$-0.146^{* \star \star}$ & -4.21 & $-0.180^{* * *}$ & -4.87 & -0.066 & -1.26 \\
\hline & & & & $0.991^{* * *}$ & 4.02 \\
\hline & & & & $-0.340 *$ & -1.88 \\
\hline & & & & 0.020 & 1.05 \\
\hline & & & & $97.137^{* * *}$ & 3. \\
\hline & & & & $0.063^{* * *}$ & \\
\hline
\end{tabular}

\begin{tabular}{rr} 
Coefficient & $t$-stat \\
\hline-0.025 & -0.80
\end{tabular}

$\begin{array}{ll}-0.025 & -0.80 \\ -0.345 * * & -2.61 \\ 1.130 * & 4.54\end{array}$

$1.130^{* * *} 4.54$

$-0.493 * * \quad-2.54$

$0.012 \quad 0.60$

$0.076 * * * \quad 3.84$

$-1.90 \mathrm{E}-07^{* * *}-4.44$

503

YES

YES

503

YES

YES

NO

423
$62.36 \%$
YES

YES

NO

255
$68.29 \%$
YES

YES

$4.63 \mathrm{E}-02 * *$

3.84
2.41

\begin{tabular}{|c|c|c|c|}
\hline Mean & $\underline{\text { St. Dev }}$ & Coefficient & t-stat \\
\hline 0.49 & 0.50 & -0.194 ** & \\
\hline 4.63 & 1.93 & $-1.755^{* * *}$ & -19 \\
\hline 9.21 & 0.88 & $0.592 *$ & 1. \\
\hline
\end{tabular}

\begin{tabular}{cc} 
Coefficient & $\mathrm{t}$-stat \\
\hline$-0.198^{* * *}$ & -3.29 \\
$-0.270^{* * *}$ & -8.81 \\
$-0.069^{*}$ & -1.76
\end{tabular}

\begin{tabular}{cc} 
Coefficient & t-stat \\
\hline$-0.214^{* * *}$ & -3.85 \\
$-0.112^{* * *}$ & -3.62 \\
$-0.135^{* * *}$ & -3.32
\end{tabular}

\begin{tabular}{cr} 
Coefficient & t-stat \\
\hline$-\mathbf{0 . 2 6 6}{ }^{* * *}$ & $\mathbf{- 2 . 7 2}$ \\
0.030 & 0.89 \\
-0.023 & -0.37 \\
$1.032^{* * *}$ & 4.00 \\
$-0.319^{*}$ & -1.97 \\
$0.029^{*}$ & 1.53 \\
48.716 & 1.43 \\
$0.072^{* * *}$ & 3.40
\end{tabular}

$-2.00 \mathrm{E}-07^{* * *}-4.70$

255

YES

\begin{tabular}{cr} 
Coefficient & $\mathrm{t}$-stat \\
\hline$-\mathbf{0 . 2 6 4}{ }^{* * *}$ & $-\mathbf{2 . 7 0}$ \\
$0.021^{* *}$ & 0.66 \\
$-0.298^{* *}$ & -2.18 \\
$1.170^{* *}$ & 4.47 \\
$-0.472^{* * *}$ & -2.67 \\
$0.021^{*}$ & 1.06 \\
$39.172^{* * *}$ & 1.17 \\
$0.085^{* *}$ & 3.91 \\
$4^{*} \mathrm{E}-02^{* *}$ & 233
\end{tabular}

$\begin{array}{rllll}503 & 503 & & & \\ 91.11 \% & 62.68 \% & 648 & 268 & 268 \\ \text { YES } & \text { YES } & \text { YES } & 69.60 \% & 70.15 \% \\ \text { YES } & \text { NO } & \text { NO } & \text { YES } & \text { YES } \\ & & \text { NO } & \text { NO }\end{array}$

Table 2. Comovement of Stocks: Proportion of Stocks moving together

The dependent variable is the proportion of stocks moving together in each country and year. For each day, we compute the maximum of the number of stocks with positive returns, and the number of stocks with negative returns, relative to the total number of stocks. We then calculate the average of this ratio for each country and year. The number of firms is the number of firms with available stock price data in Datastream, in each country and year. Country Herfindahl index is calculated as the sum of the market shares (squared) of every firm in each country and year, relative to the corresponding country's total sales. Industry Herfindahl index is calculated as the sum of the market shares (squared) of every industry in each country and year, relative to the corresponding country's total sales. The size of the country is the extension of a country in square kilometers, from Repudiation of Contract indices from La Porta et al. (1997). The Short Selling variable is a dummy variable that equals one when short selling is allowed and practiced in a given country and year, zero otherwise. The sample includes firms from 52 countries with stock price information available from Datastream. Macroeconomic variables are from the Economist Intelligence Unit database. All regressions include year-fixed effects. Standard errors are White-heteroskedasticity consistent. 
Log (Number of Firms)

Log (GDP per capita)

Country Herfindahl Index

Industry Herfindahl Index

Log (Country Size)

Variance in GDP growth

Earnings Comovement Index

Good Government Index

Dependent Variable

Number of Observations

Adjusted R-squared

Year Fixed Effects

Country Fixed Effects

\section{Log (Number of Firms) \\ Log (GDP per capita) \\ Country Herfindahl Index \\ Industry Herfindahl Index \\ Log (Country Size) \\ Variance in GDP growth \\ Earnings Comovement Index \\ Good Government Index}

Short Selling is Allowed and Practiced

Dependent Variable

Number of Observations

Adjusted R-squared

Year Fixed Effects

Country Fixed Effects

denotes significant at the $10 \%, 5 \%, 1 \%$ levels or better, respectively

$\begin{array}{ll}1.69 & 6.29\end{array}$

$23.26 \quad 5.04$

$0.22 \quad 0.20$
Dependent Variable : R-squared of regressions of Stock Returns on Market Indices

$\begin{array}{cc}\frac{\text { Mean }}{4.63} & \text { St. Dev } \\ 9.21 & 0.93 \\ 0.15 & 0.21 \\ 0.25 & 0.27 \\ 12.05 & 3.63 \\ 0.0014 & 0.0011 \\ 1.69 & 6.29 \\ 23.26 & 5.04 \\ & \\ 0.22 & 0.20\end{array}$

\begin{tabular}{crrrr} 
Coefficient & t-stat & Coefficient & t-stat & C \\
\cline { 3 - 5 }$-1.163^{* * *}$ & -12.95 & $-0.129^{* * *}$ & -6.63 \\
$-0.360^{* *}$ & -2.13 & $-0.171^{* *}$ & -4.56 \\
& & & \\
& & & \\
& & & \\
& & &
\end{tabular}

\begin{tabular}{cc} 
Coefficient & t-stat \\
\hline$-0.129^{* * *}$ & -4.05 \\
$-0.094^{*}$ & -1.86
\end{tabular}

\begin{tabular}{cr} 
Coefficient & t-stat \\
\hline-0.021 & -0.57 \\
$-0.273^{* * *}$ & -3.70 \\
-0.351 & -0.83 \\
-0.081 & -0.48 \\
$-0.091^{* * *}$ & -4.14 \\
$93.240^{* *}$ & 3.52 \\
-0.004 & -0.18
\end{tabular}

\begin{tabular}{cr} 
Coefficient & $\mathrm{t}-\mathrm{stat}$ \\
\hline-0.022 & -0.60 \\
-0.312 & -1.38 \\
-0.332 & -0.78 \\
-0.103 & -0.54 \\
$-0.092^{* * *}$ & -3.98 \\
$91.682^{* * *}$ & 3.11 \\
-0.002 & -0.10 \\
$6.51 \mathrm{E}-03$ & 0.22
\end{tabular}

503
$99.60 \%$
YES

503

YES

YES

NO

$1.09 \mathrm{E}-07$ * $\quad 1.78$

$\begin{array}{ll}255 & 255 \\ 29.52 \% & 29.30 \% \\ \text { YES } & \text { YES } \\ \text { NO } & \text { NO }\end{array}$

423
$16.13 \%$

YES

YES

NO

\begin{tabular}{|c|c|c|c|}
\hline Mean & St. Dev & Coefficient & t-stat \\
\hline 0.49 & 0.50 & -0.144 & -1.17 \\
\hline 4.63 & 1.93 & $-0.992 * * *$ & -11.40 \\
\hline 9.21 & 0.88 & 0.597 * & 1.93 \\
\hline
\end{tabular}

\begin{tabular}{cc} 
Coefficient & t-stat \\
\hline$-0.395^{* * *}$ & -4.79 \\
$-0.074^{* * *}$ & -3.39 \\
$-0.054^{*}$ & -1.20
\end{tabular}

\begin{tabular}{cr} 
Coefficient & t-stat \\
\hline$-0.367^{\star \star \star}$ & -4.20 \\
$-0.100^{* \star *}$ & -2.96 \\
$0.007^{*}$ & 0.12
\end{tabular}

\begin{tabular}{cr} 
Coefficient & t-stat \\
\hline$-0.431^{\star * \star}$ & -4.52 \\
0.047 & 1.10 \\
$-0.160^{* *}$ & -2.29 \\
-0.250 & -0.67 \\
-0.016 & -0.10 \\
$-0.072^{* * *}$ & -3.26 \\
23.107 & 0.78 \\
0.012 & 0.47
\end{tabular}

\begin{tabular}{cc} 
Coefficient & $t$-stat \\
\hline$-0.431^{\star \star *}$ & -4.52
\end{tabular}

$0.047 \quad 1.10$
-0.153

$\begin{array}{ll}-0.153 & -0.74\end{array}$

$-0.254 \quad-0.67$

$\begin{array}{lllll}0.27 & -0.016 & -0.10 & -0.012 & -0.07 \\ 3.63 & -0.072 * * * & -3.26 & -0.072 \text { *** } & -3.13 \\ 0.0011 & -0.072 & 0.78 & 23.341 & 0.74\end{array}$

$\begin{array}{lllll}0.27 & -0.016 & -0.10 & -0.012 & -0.07 \\ 3.63 & -0.072 * * * & -3.26 & -0.072 \text { *** } & -3.13 \\ 0.0011 & -0.072 & 0.78 & 23.341 & 0.74\end{array}$

0.0011

$1.05 \mathrm{E}-07$ * $\quad 1.72$

0.0120 .44

\begin{tabular}{lllll}
503 & \multicolumn{1}{r}{503} & 448 & \multicolumn{1}{c}{268} & 268 \\
$99.64 \%$ & $23.37 \%$ & $20.05 \%$ & $33.66 \%$ & $33.43 \%$ \\
YES & YES & YES & YES & YES \\
YES & NO & NO & NO & NO
\end{tabular}

268

NO

Table 3. Comovement of Stocks: R-squared

The dependent variable is the average R-squared of by-firm and year regressions of weekly stock returns on the market index. The number of firms is the number of firms with available stock price data in Datastream, in each country and year. Country Herfindahl index is calculated as the sum of the market shares (squared) of every firm in each country and year, relative to the corresponding country's total sales. Industry Herfindahl index is calculated as the sum of the market shares (squared) of every industry in each country and year, relative to the corresponding country's total sales. The size of the country is the extension of a country in square kilometers, from www.yahoo.com. The earnings comovement index is calculated as in Morck et al. (2000). The Good Government index is the sum of the Risk of Expropriation, Corruption, and Repudiation of Contract indices from La Porta et al. (1997). The Short Selling variable is a dummy variable that equals one when short selling is allowed and practiced in a given country and year, zero otherwise. The sample includes firms from 52 countries with stock price information available from Datastream. Macroeconomic variables are from the Economist Intelligence Unit database. All regressions include year-fixed effects. Standard errors a 
Dependent Variable: Mean Skewness of Individual Stock Raw Returns

Short Selling Allowed \& Practiced

Log (Number of Firms)

Log (GDP per capita)

Country Herfindahl Index

Industry Herfindahl Index

Log (Country Size)

Variance in GDP growth

Earnings Comovement Index

Good Government Index

Lagged Turnover

Lagged Market Return

Dependent Variable

Number of Observations

Adjusted R-squared

Year Fixed Effects

Country Fixed Effects

\begin{tabular}{|c|c|c|c|c|c|}
\hline Mean & $\underline{\text { St. Dev }}$ & Coeff. & t-stat & Coeff. & t-stat \\
\hline 0.49 & 0.50 & -0.010 & -0.10 & & \\
\hline 4.63 & 1.93 & -0.049 & -0.30 & 0.214 & 1.15 \\
\hline 9.21 & 0.88 & 0.092 & 0.15 & -0.742 * & -1.90 \\
\hline 0.15 & 0.21 & & & & \\
\hline 0.25 & 0.27 & & & & \\
\hline 12.05 & 3.63 & & & & \\
\hline 0.00 & 0.00 & & & & \\
\hline 1.69 & 6.29 & & & & \\
\hline 23.26 & 5.04 & & & & \\
\hline 0.073 & 0.406 & & & & \\
\hline
\end{tabular}

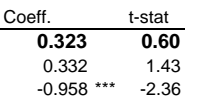

\begin{tabular}{cc} 
Coeff. & t-stat \\
\hline $\mathbf{- 1 . 9 8 3}$ & $\mathbf{- 2 . 2 4}$ \\
-0.240 & -0.53 \\
-1.131 & -1.41 \\
1.957 & 0.59 \\
-2.096 & -0.92 \\
$0.370^{*}$ & 1.77 \\
$-843.526^{* *}$ & -2.23 \\
0.402 ** & 2.04
\end{tabular}

\begin{tabular}{cc} 
Coeff. & t-stat \\
\hline$-2.021^{* *}$ & -2.32 \\
-0.053 & -0.10 \\
$3.887^{* * *}$ & 3.02 \\
-0.746 & -0.22 \\
0.819 & 0.33 \\
$0.519^{* *}$ & 2.57 \\
-685.497 & -2.01 \\
0.180 & 0.95 \\
$-8.45 \mathrm{E}-01^{* * *}$ & -3.41 \\
-0.001 & -0.07 \\
$-0.066^{* *}$ & -2.30
\end{tabular}

$\begin{array}{lll}300 & 300 & 300 \\ 6.02 \% & 9.29 \% & 3.42 \% \\ \text { YES } & \text { YES } & \text { YES } \\ \text { NO } & \text { NO } & \text { NO }\end{array}$

NO

\section{0}

Dependent Variable: Skewness of Market Returns

Short Selling Allowed \& Practiced
Log (Number of Firms)
Log (GDP per capita)
Country Herfindahl Index
Industry Herfindahl Index
Log (Country Size)
Variance in GDP growth
Earnings Comovement Index
Good Government Index
Lagged Turnover
Lagged Market Return
Dependent Variable
Number of Observations
Adjusted R-squared

Adjusted R-squared

Year Fixed Effects

$-0.095$

0.484

503
$14.78 \%$

$14.78 \%$

YES

503
$2.03 \%$
YES

503
$2.53 \%$

YES

\begin{tabular}{|c|c|c|c|c|c|c|c|}
\hline Mean & $\underline{\text { St. Dev }}$ & Coeff. & t-stat & Coeff. & t-stat & Coeff. & $\mathrm{t}$-stat \\
\hline 0.49 & 0.50 & $\begin{array}{l}-1.021 \\
\end{array}$ & -1.37 & & & -0.087 & -0.63 \\
\hline 4.63 & 1.93 & 1.870 ** & 2.17 & $-0.057^{*}$ & -1.74 & -0.061 & -1.58 \\
\hline 9.21 & 0.88 & -3.006 & -0.86 & $-0.226^{\star \star \star *}$ & -3.05 & -0.204 ** & -2.25 \\
\hline 0.15 & 0.21 & & & & & & \\
\hline 0.25 & 0.27 & & & & & & \\
\hline 12.05 & 3.63 & & & & & & \\
\hline 0.00 & 0.00 & & & & & & \\
\hline 1.69 & 6.29 & & & & & & \\
\hline 23.26 & 5.04 & & & & & & \\
\hline 0.073 & 0.406 & & & & & & \\
\hline
\end{tabular}

\begin{tabular}{rr}
\multicolumn{1}{c}{ Coeff. } & \multicolumn{1}{c}{-stat } \\
\hline $\mathbf{- 0 . 2 1 9}$ & $\mathbf{- 1 . 0 6}$ \\
0.005 & 0.05 \\
-0.235 & -1.47 \\
0.421 & 0.78 \\
$-0.9955^{* \star *}$ & -3.01 \\
-0.073 & -1.04 \\
$-186.803^{* * *}$ & -3.50 \\
-0.124 & -1.59
\end{tabular}

\begin{tabular}{|c|c|c|c|}
\hline Coeff. & t-stat & Coeff. & t-stat \\
\hline-0.222 & -1.07 & -0.246 & -1.19 \\
\hline 0.015 & 0.16 & 0.076 & 0.72 \\
\hline 0.083 & 0.22 & 0.009 & 0.02 \\
\hline 0.261 & 0.49 & 0.332 & 0.64 \\
\hline$-0.817^{* \star}$ & -2.22 & -0.878 ** & -2.38 \\
\hline-0.064 & -0.90 & -0.076 & -1.08 \\
\hline$-175.745^{* * *}$ & -3.24 & $-199.895 * * *$ & -3.38 \\
\hline-0.138 * & -1.74 & -0.149 * & -1.90 \\
\hline \multirow[t]{3}{*}{$-5.30 \mathrm{E}-02$} & -1.14 & $-4.38 \mathrm{E}-02$ & -0.93 \\
\hline & & -0.004 ** & -2.46 \\
\hline & & -0.002 & -0.22 \\
\hline
\end{tabular}

$1.745 \quad 5.809$

$\begin{array}{lccccc}503 & & & & 300 & 300.000 \\ 70.75 \% & 503 & 503 & 300 & 300 & 3.99 \% \\ \text { YES } & 5.97 \% & 5.62 \% & 2.59 \% & 2.68 \% & \text { YES } \\ \text { YES } & \text { YES } & \text { YES } & \text { YES } & \text { NO } & \text { NO }\end{array}$

Dependent Variable: Mean Skewness of Individual Stock Abnormal Returns

Short Selling Allowed \& Practiced

Log (Number of Firms)

Country Herfindahl Index
Industry Herfindahl Index

Log (Country Size)

Variance in GDP growth

Earnings Comovement Index

Good Government Index

Lagged Turnover

Lagged Market Return

Dependent Variable

Number of Observations

Adjusted R-squared

Year Fixed Effects

Country Fixed Effects

\begin{tabular}{|c|c|c|c|c|c|}
\hline Mean & $\underline{\text { St. Dev }}$ & Coeff. & t-stat & Coeff. & t-stat \\
\hline 0.49 & 0.50 & 0.007 & 0.08 & & \\
\hline 4.63 & 1.93 & -0.165 & -1.42 & 0.106 & 0.71 \\
\hline 9.21 & 0.88 & -0.289 & -0.88 & -0.227 & -0.75 \\
\hline 0.15 & 0.21 & & & & \\
\hline 0.25 & 0.27 & & & & \\
\hline 12.05 & 3.63 & & & & \\
\hline 0.0014 & 0.0011 & & & & \\
\hline 1.69 & 6.29 & & & & \\
\hline 23.26 & 5.04 & & & & \\
\hline 0.073 & 0.406 & & & & \\
\hline 0.022 & 0.384 & & & & \\
\hline \multirow[t]{4}{*}{-0.162} & 0.395 & & & & \\
\hline & & 503 & & 503 & \\
\hline & & $40.43 \%$ & & $1.78 \%$ & \\
\hline & & YES & & YES & \\
\hline
\end{tabular}

\begin{tabular}{ccc} 
Coeff. & t-stat & \\
\hline $\mathbf{0 . 2 7 7}$ & $\mathbf{0 . 5 5}$ & \\
0.139 & 0.73 & \\
-0.236 & -0.69
\end{tabular}

\begin{tabular}{|c|c|}
\hline & t-stat \\
\hline$-1.743^{\star \star}$ & -2.47 \\
\hline-0.262 & -0.63 \\
\hline-0.212 & -0.41 \\
\hline 3.169 & 1.26 \\
\hline-2.086 & -1.10 \\
\hline 0.180 & 1.18 \\
\hline-717.867 *** & -2.82 \\
\hline 0.362 ** & 2.21 \\
\hline
\end{tabular}

\begin{tabular}{cc} 
Coeff. & t-stat \\
\hline $\mathbf{- 1 . 7 7 7}$ & $\mathbf{- 2 . 5 4}$ \\
-0.124 & -0.30 \\
$4.128^{\star \star \star}$ & 3.44 \\
0.984 & 0.39 \\
0.342 & 0.17 \\
$0.304^{*}$ & 1.89 \\
$-567.098^{* \star}$ & -2.39 \\
0.166 & 1.07 \\
$-7.22 \mathrm{E}-01^{* \star *}$ & -3.95
\end{tabular}

$\frac{\text { Coeff. }}{-1.955^{\star \star \star}-2.87}$

$\begin{array}{ll}0.157 & 0.39 \\ 3.867 * * * & 3.31 \\ 1.138 & 0.46\end{array}$

$\begin{array}{ll}0.157 & 0.39 \\ 1.138 & 0.36\end{array}$

0.233

$\begin{array}{ll}0.263^{*} & 0.11 \\ 0.71\end{array}$

$-666.787 * * * \quad-2.87$

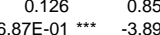

$\begin{array}{lr}0.017 * & -3.89 \\ -0.010 & 0.54\end{array}$

300.000

$11.85 \%$

NO

503
$1.83 \%$
YES

NO

$\begin{array}{lll}300 & 300 & 300.000 \\ 6.47 \% & 10.81 \% & 11.85 \% \\ \text { YES } & \text { YES } & \text { YES } \\ \text { NO } & \text { NO } & \text { NO }\end{array}$

Table 4. Short Selling Restrictions and Skewness of Stock Return

The dependent variable is the skewness of $\log (1+\mathrm{r})$, where $\mathrm{r}$ denotes stock returns in each country and year. The skewness of raw returns is calculated as the skewness of the total sample of weekly stock returns in each country and year. The skewness of abnormal returns is the skewness of $\log (1+\mathrm{u})$, where $\mathrm{u}$ is the residual of a regression of weekly stock returns on the market index, for each firm in every price data in Datastream, in each country and year. Country Herfindahl index is calculated as the sum of the market shares (squared) of every firm in each country and year, relative to the corresponding country's total sales. Industry Herfindahl index is calculated as the sum of the market shares (squared) of every industry in each country and year, relative to the corresponding country's total sales. The size of the country is the extension of a country in square kilometers, from www.yahoo.com. The earnings comovement index is calculated as in Morck et al. (2000). The Good Government index is the sum of the Risk of Expropriation, Corruption, and Repudiation of Contract indices from La Porta et al. (1997). The Short Selling variable is a dummy variable that equals one when short selling is allowed and practiced in a given country and year, zero otherwise. The sample includes firms from 52 countries with stock price information available from Datastream. Macroeconomic variables are from the Economist Intelligence Unit database. All regressions include year-fixed effects. Standard errors are White-heteroskedasticity consistent. 


\section{Dependent Variable : Average Standard Deviation of Individual Stock Returns}

\begin{tabular}{|c|c|c|c|c|c|c|c|c|c|c|c|c|}
\hline & Mean & St. Dev & Coefficient & t-stat & Coefficient & t-stat & Coefficient & t-stat & Coefficient & t-stat & Coefficient & t-stat \\
\hline Short Selling is Allowed and Practiced & 0.49 & 0.50 & 0.058 & 1.33 & $-0.101^{\star \star \star}$ & -3.19 & $-0.103^{\star \star \star}$ & -3.14 & $-0.100^{\star \star \star}$ & -3.05 & $-0.260 * \star \star$ & -7.02 \\
\hline Log (Number of Firms) & 4.63 & 1.93 & 0.047 & 0.95 & $0.051 * * *$ & 4.96 & $0.046 * * *$ & 3.25 & $0.068^{* * *}$ & 4.60 & $0.097^{* * *}$ & 5.96 \\
\hline Log (GDP per capita) & 9.21 & 0.88 & -0.081 & -0.52 & $-0.147^{* * *}$ & -9.89 & $-0.112^{* * *}$ & -5.97 & 0.020 & 0.44 & 0.028 & 0.54 \\
\hline Country Herfindahl Index & 0.15 & 0.21 & & & & & 0.156 & 1.59 & $0.324 * *$ & 2.42 & -0.041 & -0.48 \\
\hline Industry Herfindahl Index & 0.25 & 0.27 & & & & & -0.075 & -1.07 & -0.170 ** & -2.36 & -0.018 & -0.30 \\
\hline Log (Country Size) & 12.05 & 3.63 & & & & & 0.001 & 0.11 & -0.002 & -0.34 & $0.032 * * *$ & 4.82 \\
\hline Variance in GDP growth & 0.0014 & 0.0011 & & & & & $80.493^{\star \star \star}$ & 6.03 & $81.662^{\star \star \star}$ & 6.16 & 10.073 & 0.71 \\
\hline Earnings Comovement Index & 1.69 & 6.29 & & & & & & & & & $0.064^{\star * *}$ & 4.85 \\
\hline Good Government Index & 23.26 & 5.04 & & & & & & & $-0.021^{\star \star \star}$ & -3.03 & $-0.021^{* \star *}$ & -2.81 \\
\hline Dependent Variable & 0.046 & 0.016 & & & & & & & & & & \\
\hline Number of Observations & & & 503 & & 503 & & 454 & & 416 & & 264 & \\
\hline Adjusted R-squared & & & $97.28 \%$ & & $99.27 \%$ & & $99.35 \%$ & & $99.35 \%$ & & $99.69 \%$ & \\
\hline Year Fixed Effects & & & YES & & YES & & YES & & YES & & YES & \\
\hline Country Fixed Effects & & & YES & & NO & & NO & & NO & & NO & \\
\hline
\end{tabular}

${ }^{* *},{ }^{* \star \star}$ denotes significant at the $10 \%, 5 \%, 1 \%$ levels or better, respectively

Table 5. Distribution of Stock Returns and Short-Selling Restrictions

The dependent variable is the standard deviation of individual stock returns, averaged across countries and years. The number of firms is the number of firms with available stock price data in Datastream, in each country and year. Country Herfindahl index is calculated as the sum of the market shares (squared) of every firm in each country and year, relative to the corresponding country's total sales. Industry Herfindahl index is calculated as the sum of the market shares (squared) of every industry in each country and year, relative to the corresponding country's total sales. The size of the country is the extension of a country in square kilometers, from www.yahoo.com. The earnings comovement index is calculate as in Morck et al. (2000). The Good Government index is the sum of the Risk of Expropriation, Corruption, and Repudiation of Contract indices from La Porta et al. (1997). The Short Selling variable is a dummy variable that equals one when short selling is allowed and practiced in a given country and year, zero otherwise. The sample includes firms from 52 countries with stock price information available from Datastream. Macroeconomic variables are from the Economist Intelligence Unit database. All regressions include yearfixed effects. Standard errors are White-heteroskedasticity consistent. 
Dependent Variable : Frequency of Extreme Results (Less than 2 x St. Dev)

Short Selling is Allowed and Practiced

Log (GDP per capita)

Country Herfindahl Index

Industry Herfindahl Index

Log (Country Size)

Variance in GDP growth

Earnings Comovement Index

Good Government Index

Dependent Variable

Number of Observations

Adjusted R-squared

Year Fixed Effects

Country Fixed Effects

$\begin{array}{ccr}\frac{\text { Mean }}{0.49} & \text { St. Dev } & \text { Coefficient } \\ 9.21 & 0.50 & \mathbf{0 . 1 3 5} \\ 0.88 & 0.355\end{array}$

t-stat

\begin{tabular}{r} 
Coefficient \\
\hline-0.009 \\
-0.038
\end{tabular}

0.27

$\begin{array}{ll}12.05 & 3.63 \\ 0.0014 & 0.0011\end{array}$

t-stat

\begin{tabular}{rr} 
Coefficient & t-stat \\
\hline-0.030 & -0.49 \\
-0.048 & -0.90 \\
0.212 & 1.08 \\
-0.159 & -1.37 \\
-0.004 & -0.29 \\
-31.398 & -1.12
\end{tabular}

$\frac{\text { Coefficient }}{-0.010}$

$\begin{array}{rrr} & \text { efficient } & \text { t-stat } \\ -0.010 & -0.16 & \\ 0.016 & 0.15\end{array}$

$\begin{array}{ll}0.016 & 0.15 \\ 0.059 & 0.18\end{array}$

$\begin{array}{ll}-0.133 & -0.72 \\ -0.001 & -0.09\end{array}$

$-0.001-0.09$

$\begin{array}{rr}-0.001 & -0.09 \\ -14.869 & -0.51\end{array}$

$-0.51$

$-0.006$

$-0.41$

Coefficient

$-0.169^{* *}-2.18$

$0.043 \quad 0.38$

$0.332 \quad 0.93$

$\begin{array}{ll}-0.120 & -0.67\end{array}$

$\begin{array}{rr}0.018 & 1.31 \\ -25.764 & -0.74\end{array}$

$-25.764 \quad-0.74$

$23.26 \quad 5.04$

$0.07 \quad 0.09$

$503 \quad 503 \quad 465$

269

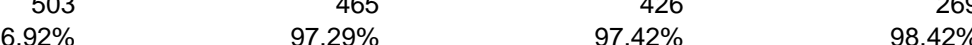

YES YES

YES

YES

YES

YES

YES

\section{Table 6. Frequency of Extreme Returns and Short-Selling Restrictions}

The dependent variables is the per year number of trading days where the market return is lower than the average market return minus two standard deviations, divided by the total number of trading days. The endogenous variable is mapped on the set of real numbers, with the transformation $\log (\mathrm{x} /(1-\mathrm{x}))$. The mean and standard deviation of the market return is calculated over the same country and year. Country Herfindahl index is calculated as the sum of the market shares (squared) of every firm in each country and year, relative to the corresponding country's total sales. Industry Herfindahl index is calculated as the sum of the market shares (squared) of every industry in each country and year, relative to the corresponding country's total sales. The size Morck ex (2000). The Goveriation, Corruption, and Repudiation of Contract indices from La Porta et al. (1997). The Short Selling stoc pre errors 


\begin{tabular}{|c|c|c|c|c|c|c|}
\hline $\begin{array}{c}\text { Years Relative } \\
\text { to Change in } \\
\text { Law }\end{array}$ & $\begin{array}{l}\text { Hong } \\
\text { Kong }\end{array}$ & Malaysia & Norway & Sweden & Thailand & Average \\
\hline-7 & & & & & $4.85 \%$ & $4.85 \%$ \\
\hline-6 & $1.63 \%$ & & & & $7.58 \%$ & $4.60 \%$ \\
\hline-5 & $4.60 \%$ & $3.88 \%$ & & & $4.78 \%$ & $4.42 \%$ \\
\hline-4 & $4.64 \%$ & $4.61 \%$ & & & $5.46 \%$ & $4.90 \%$ \\
\hline-3 & $4.52 \%$ & $4.68 \%$ & & & $6.58 \%$ & $5.26 \%$ \\
\hline-2 & $3.50 \%$ & $4.07 \%$ & $1.87 \%$ & & $5.54 \%$ & $3.74 \%$ \\
\hline-1 & $3.38 \%$ & $5.06 \%$ & $2.08 \%$ & $1.57 \%$ & $4.91 \%$ & $3.40 \%$ \\
\hline 0 & $4.17 \%$ & $3.37 \%$ & $3.59 \%$ & $1.79 \%$ & $3.02 \%$ & $3.19 \%$ \\
\hline 1 & $4.44 \%$ & $5.93 \%$ & $3.78 \%$ & $1.86 \%$ & $2.45 \%$ & $3.69 \%$ \\
\hline 2 & $3.18 \%$ & $4.86 \%$ & $3.42 \%$ & $2.96 \%$ & $1.69 \%$ & $3.22 \%$ \\
\hline 3 & $3.99 \%$ & $2.29 \%$ & $5.07 \%$ & $4.00 \%$ & $2.23 \%$ & $3.82 \%$ \\
\hline 4 & $6.75 \%$ & $3.04 \%$ & $5.27 \%$ & $2.78 \%$ & $2.87 \%$ & $4.42 \%$ \\
\hline 5 & $7.36 \%$ & $4.50 \%$ & $10.71 \%$ & $3.78 \%$ & & $7.28 \%$ \\
\hline 6 & & $3.80 \%$ & $5.65 \%$ & $8.56 \%$ & & $7.10 \%$ \\
\hline 7 & & & $1.98 \%$ & $5.02 \%$ & & $3.50 \%$ \\
\hline 8 & & & $5.05 \%$ & $5.39 \%$ & & $5.22 \%$ \\
\hline 9 & & & $2.84 \%$ & $5.75 \%$ & & $4.29 \%$ \\
\hline 10 & & & & $2.93 \%$ & & $2.93 \%$ \\
\hline Law Changed in: & 1996 & 1995 & 1992 & 1991 & 1997 & \\
\hline
\end{tabular}

Table 7. Frequency of Extreme Returns and Short-Selling Restrictions. Countries with Regulatory changes only

Number of trading days where the market return is lower than the average market return minus two standard deviations, divided by the total number of trading days, around the elimination of short selling restrictions. Only the five countries with regulatory changes between 1990 and 2001-Hong Kong, Norway, Sweden, Malaysia, and Thailand-are considered. The sample includes firms from these countries with stock price information available from Datastream. For each firm and year, we calculate the mean and standard deviation of returns, and calculate the number of days where the return is below the average return, minus two standard deviation. We aggregate this number by country and year, and divide by the total number of firm-days in the year with available stock price information. 
Dependent Variable : Frequency of Negative Extreme Returns (Less than 2 x St. Dev)

\begin{tabular}{|c|c|c|c|c|c|c|c|c|c|c|c|c|}
\hline & Mean & St. Dev & Coefficient & t-stat & Coefficient & t-stat & Coefficient & t-stat & Coefficient & t-stat & Coefficient & t-stat \\
\hline Short Selling is Allowed and Practiced & $\overline{0.33}$ & $\overline{0.48}$ & $0.395^{*}$ & $\overline{1.91}$ & 0.295 & 1.62 & $0.315^{*}$ & 1.66 & 0.326 * & 1.77 & 0.214 & 1.16 \\
\hline Log (GDP per capita) & 9.44 & 0.73 & -1.241 & -1.11 & $-0.173^{* *}$ & -2.06 & $-0.341 * *$ & -2.10 & 2.666 ** & 2.61 & 1.821 & 1.59 \\
\hline Country Herfindahl Index & 0.09 & 0.09 & & & & & 2.271 & 1.17 & $6.013^{* * *}$ & 3.11 & 0.059 & 0.02 \\
\hline Industry Herfindahl Index & 0.24 & 0.28 & & & & & 0.025 & 0.04 & -0.874 & -1.46 & 7.520 ** & 2.53 \\
\hline Log (Country Size) & 11.71 & 2.39 & & & & & $-0.070^{* *}$ & -2.08 & $0.295 * *$ & 2.28 & 18.496 *** & 2.96 \\
\hline Variance in GDP growth & 0.0021 & 0.0015 & & & & & -19.711 & -0.40 & $-917.378^{* * *}$ & -3.03 & $-5154.825^{* * *}$ & -3.69 \\
\hline Earnings Comovement Index & 1.36 & 2.46 & & & & & & & & & $17.810^{* * \star}$ & 2.90 \\
\hline Good Government Index & 25.43 & 3.63 & & & & & & & $-0.843^{* * *}$ & -2.97 & $-2.450 * * *$ & -4.54 \\
\hline Dependent Variable & 0.06 & 0.03 & & & & & & & & & & \\
\hline Number of Observations & & & 45 & & 45 & & 37 & & 37 & & 37 & \\
\hline Adjusted R-squared & & & $99.23 \%$ & & $98.28 \%$ & & $98.39 \%$ & & $98.54 \%$ & & $98.71 \%$ & \\
\hline Year Fixed Effects & & & YES & & YES & & YES & & YES & & YES & \\
\hline Country Fixed Effects & & & YES & & NO & & NO & & NO & & NO & \\
\hline
\end{tabular}

Table 8. Frequency of Extreme Returns and Short-Selling Restrictions. Countries with Regulatory changes only

The dependent variables is the per year number of trading days where the market return is lower than the average market return minus two standard deviations, divided by the total number of trading days. The endogenous variable is mapped on the set of real numbers, with the transformation $\log (\mathrm{x} /(1-\mathrm{x}))$. The mean and standard deviation of the market return is calculated over the same country and year. Country Herfindahl index is calculated as the sum of the market shares (squared) of every firm in each country and year, relative to the corresponding country's total sales. Industry Herfindahl index is calculated as the sum of the market shares (squared) of every industry in each country and year, relative to the corresponding country's total sales. The size of the country is the extension of a country in square kilometers, from www.yahoo com. The earnings comovement index is calculated as in Morck et al. (2000). The Good Govenmt index is the sum of the Risk of Expropriation, Corruption, and Repudiation of Contract indices from La Porta et al. (1997). The Short Selling a a

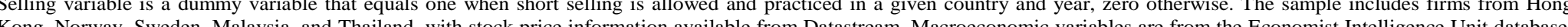

All regressions include year-fixed effects. Standard errors are White-heteroskedasticity consistent. 


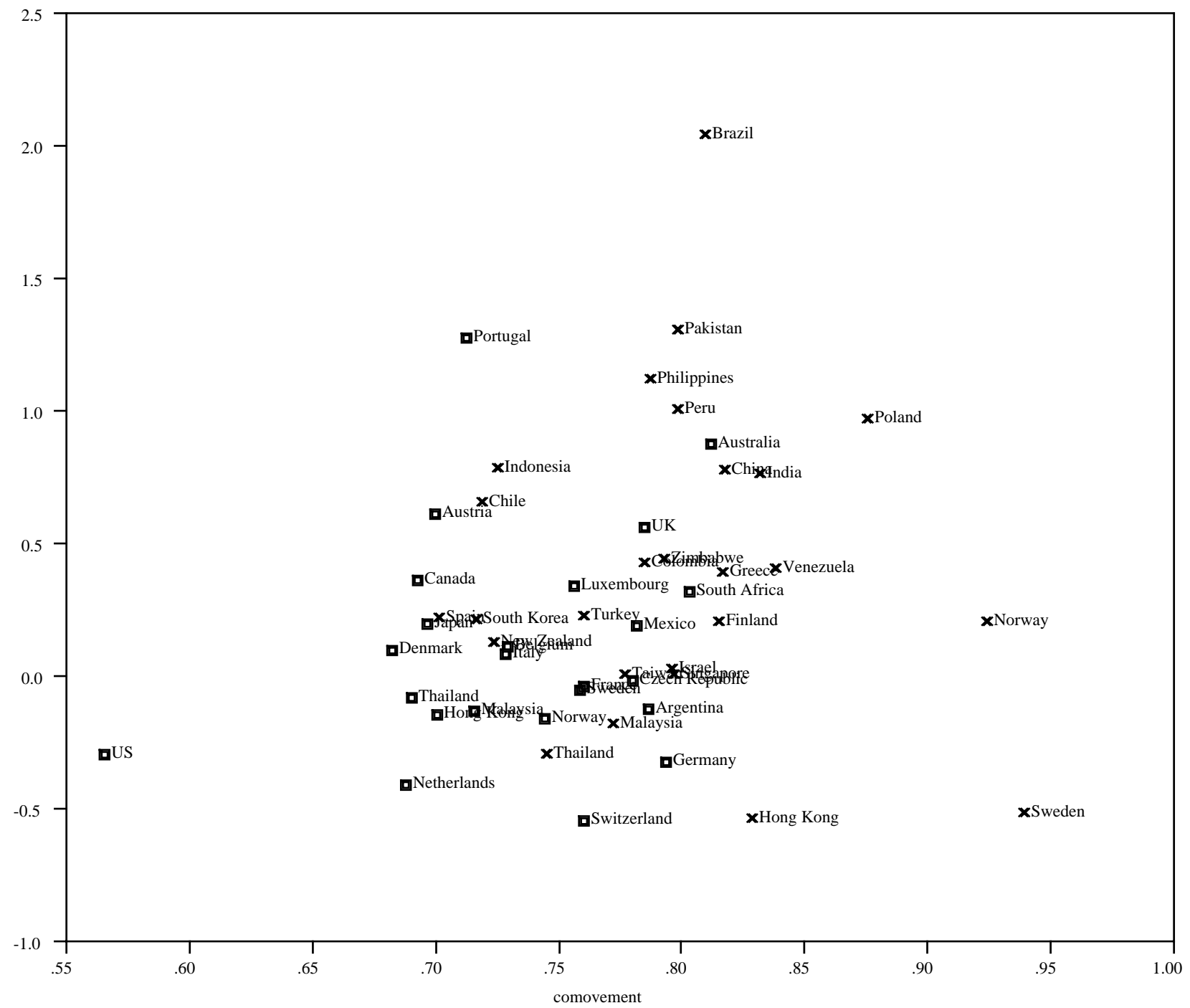

\section{Figure 1. Comovement of Stock Returns and Short Sales Restrictions}

Proportion of Stocks Comoving together agains skewness of market returns. For each day, we compute the maximum of the number of stocks with positive returns, and the number of stocks with negative returns, relative to the total number of stocks. We then calculate the average of this ratio for each country and year. Countries are classified depending on whether short sales are allowed and practiced (boxes), or not (crosses). The sample includes firms from 52 countries with stock price information available from Datastream. 


\section{Short Selling Not Allowed / Not Practiced}

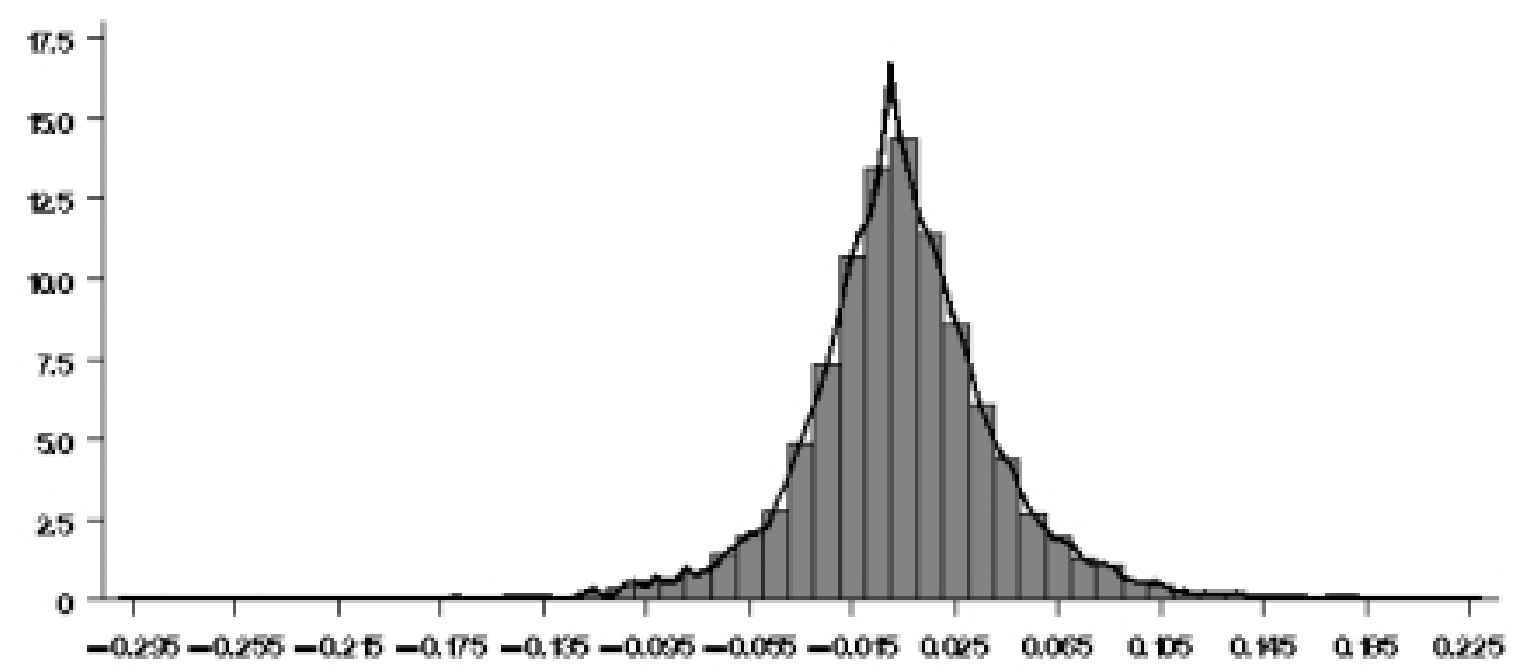

\section{Short Selling Allowed and Practiced}

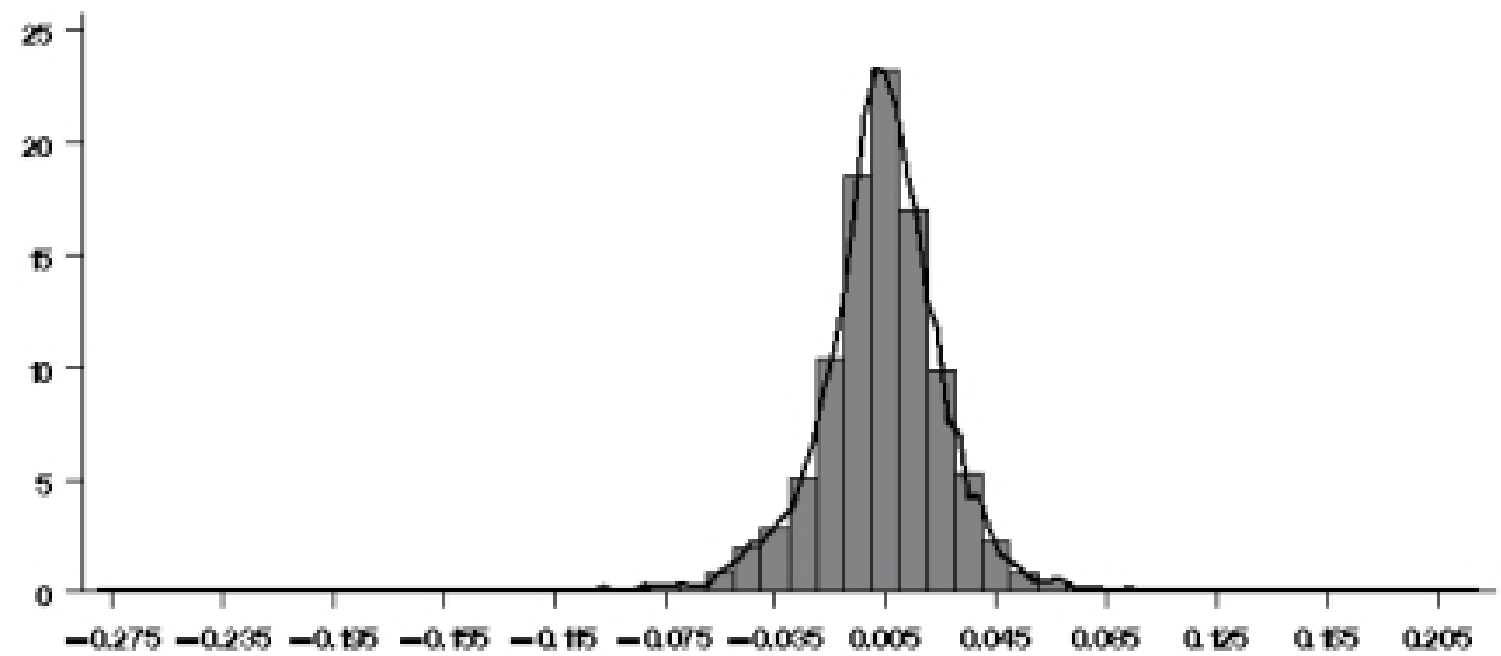

\section{Figure 2. Kernel Density Estimation}

Histogram and kernel density estimation of weekly market log-returns, depending on the existence of short-selling restrictions. The Kernel Density is estimated as detailed in footnote 15. The Short Selling variable is a dummy variable that equals one when short selling is allowed and practiced in a given country and year, zero otherwise. The sample includes firms from 52 countries with stock price information available from Datastream. Returns are pooled across years. The first two graphs corresponds to all the countries in the sample. The last to figures consider only the countries that have changed their regulation during the sample period-Hong Kong, Malaysia, Norway, Sweden, and Thailand. 
Short Selling Not Allowed / Not Practiced. Countries with Changes in Regulation

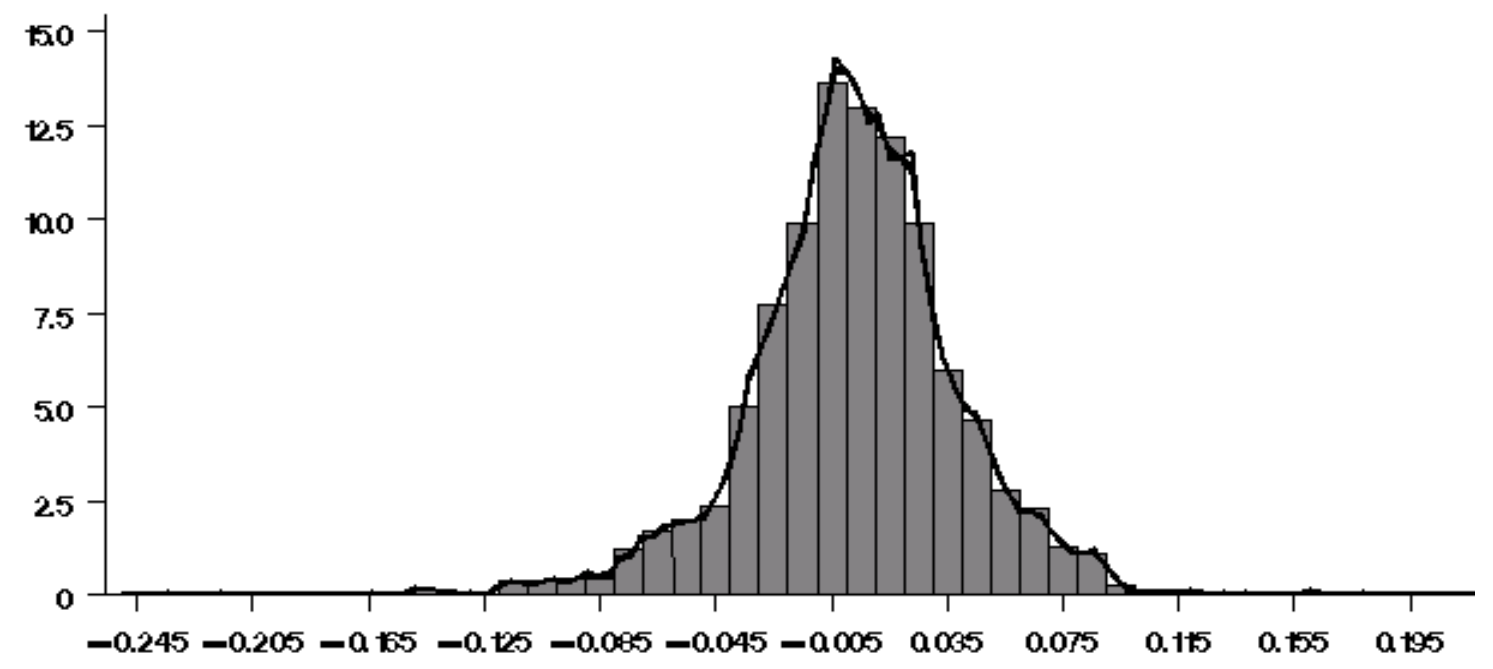

Short Selling Allowed and Practiced. Countries with Changes in Regulation

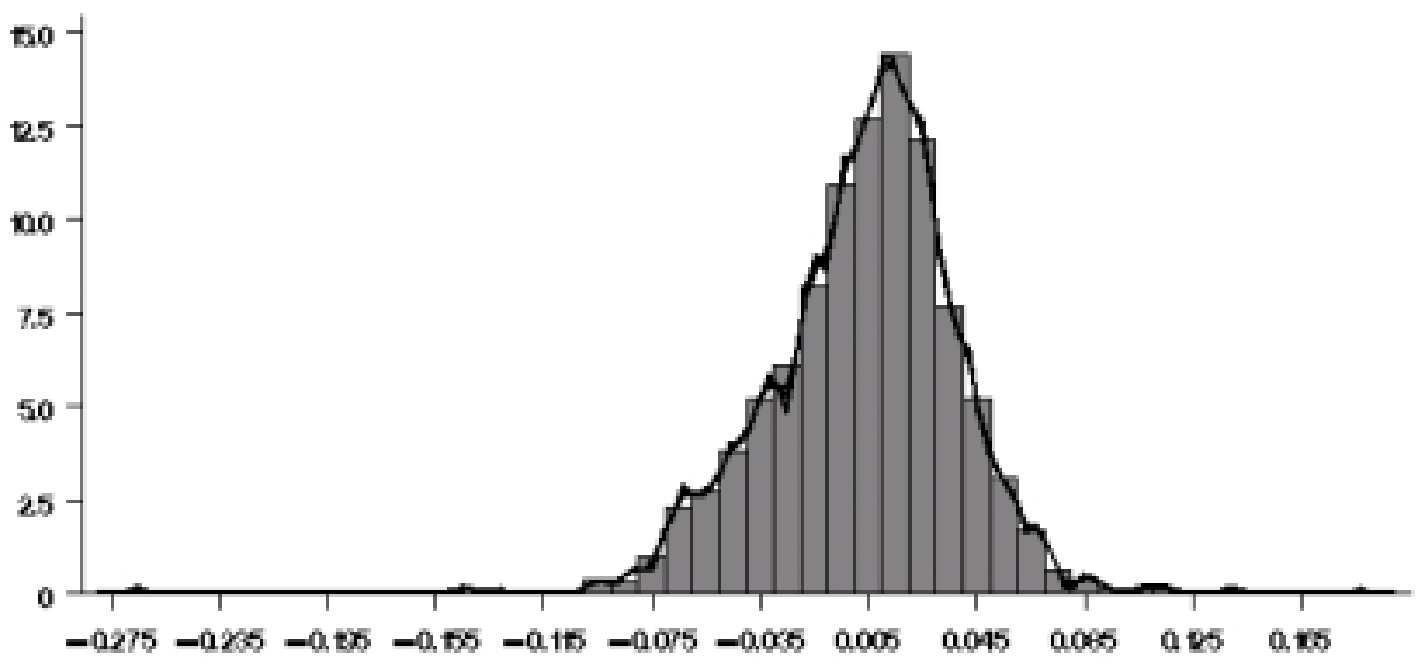

Figure 2. Kernel Density Estimation (cont) 